Article

\title{
Seismic Strengthening of the Bagh Durbar Heritage Building in Kathmandu Following the Gorkha Earthquake Sequence
}

\author{
Rabindra Adhikari ${ }^{1,2}$, Pratyush Jha ${ }^{2,3}$, Dipendra Gautam ${ }^{4, *}$ and Giovanni Fabbrocino ${ }^{4,5}$ \\ 1 Department of Civil Engineering, Cosmos College of Management and Technology, Lalitpur 44600, Nepal; \\ rabindraadhi@cosmoscollege.edu.np \\ 2 Interdisciplinary Research Institute for Sustainability, IRIS, Kathmandu 44600, Nepal; \\ pratyush0119@gmail.com \\ 3 Digicon Engineering Consult, Lalitpur 44600, Nepal \\ 4 Structural and Geotechnical Dynamics Laboratory, StreGa, DiBT, University of Molise, Via F. de Sanctis, CB \\ 86100 Campobasso, Italy; giovanni.fabbrocino@unimol.it \\ 5 ITC-CNR, Construction Technologies Institute, National Research Council of Italy (CNR), L'Aquila Branch, \\ Via Carducci, AQ 67100 L'Aquila, Italy \\ * Correspondence: dipendra.gautam@unimol.it; Tel.: +39-3388569678
}

Received: 27 April 2019; Accepted: 20 May 2019; Published: 22 May 2019

check for updates

\begin{abstract}
The so-called Greco-Roman monuments, also known as neoclassical monuments, in Nepal represent unique construction systems. Although they are not native to Nepal, they are icons of the early 19th century in the Kathmandu valley. As such structures are located within the heritage sites and historical centers, preservation of Greco-Roman monuments is necessary. Since many buildings are in operation and accommodate public and critical functions, their seismic safety has gained attention in recent times, especially after the Gorkha earthquake. This paper first presents the background of the Bagh Durbar monument, reports the damage observations, and depicts some repair and retrofitting solutions. Attention is paid to the implementation of the different phases of the structural characterization of the building, the definition of reference material parameters, and finally, the structural analysis made by using finite element models. The aim of the contribution consists of comparison of the adequacy of the finite element model with the field observations and design of retrofitting solutions to assure adequate seismic safety for typical Greco-Roman buildings in Nepal. Thus, this paper sets out to provide rational strengthening solutions compatible with the existing guidelines rather than complex numerical analyses.
\end{abstract}

Keywords: seismic assessment; Greco-Roman construction; masonry building; seismic retrofitting; heritage construction; structural restoration

\section{Introduction}

On 25 April, 2015, a strong earthquake of magnitude 7.8 occurred at the Barpak neighborhood of the Gorkha district and affected central, eastern, and some western parts of Nepal. Per the National Planning Commission, as many as one million buildings were affected by the earthquake [1]. The earthquake caused 8790 fatalities and 22,300 injuries in 31 out of 75 districts in Nepal. At least 2900 cultural heritage buildings and monuments were damaged due to the main shock and the major aftershocks of 25 April $\left(M_{W}\right.$ 6.7), 26 April $\left(M_{W}\right.$ 6.9), and 12 May $\left(M_{W} 7.3\right)$ of 2015. Gautam et al. [2] highlighted the vulnerability of Greco-Roman monuments in their recent contribution and placed them under European Macroseismic Scale (EMS-98) vulnerability class B. In Nepal, Greco-Roman heritage construction evolved in the 19th century and construction of such buildings was limited to the major 
urban as well as administrative centers of the country. Greco-Roman structures have relatively thicker brick masonry walls than other existing building forms in Nepal. They are primarily characterized by arches above the doors and windows and are multi-storied constructions. In most cases, multiple buildings are constructed as a jointed form to give rise to an aggregate system. Similarly, large structural, as well as false columns, are distinguishing features of Greco-Roman structural form. The name Greco-Roman is given as they possess the characteristics of both Greek and Roman monumental forms. The Gorkha earthquake damaged most of the Greco-Roman buildings in the Kathmandu valley including, for example, the main administrative center Singha Durbar, Administrative Staff College Jawalakhel, Babar Mahal, and Tangal Durbar, among others [3]. Although the construction age of such buildings was not similar neither comparable, damage occurrence was consistent in terms of the extent of damage in the massive walls.

Several historical earthquakes, such as 2003 Bam, 2009 L'Aquila, 2010 Chile, and 2016 Central Italy, among others, have reflected widespread damage to heritage structures (see e.g., [4-7]). The complex behavior of masonry structures is long discussed (e.g., [8-12], thus, the difficulties in seismic assessment are clear to the technical community. Existing literature on the numerical analysis of heritage structures by non-linear analyses documents well the complexity of the task and the uncertainties which remain unresolved in the interpretation of the seismic behavior of heritage masonry structures (see for e.g., [13-17]). The knowledge of structural features of heritage buildings, as well as of the material properties to be used in the safety assessment and retrofitting of existing structures, represents another complex task for engineers due to limitations arising from lack of destructive tests in heritage constructions [18,19]. Historical structures represent a particular time frame and the exact material properties and degradation cannot be adequately modeled. Greco-Roman monuments are important buildings in Nepal due to their continued use in the present time and also due to recognition as archeologically important buildings by the Department of Archeology, government of Nepal, as most of them are more than 100 years old. Limited works related to Greco-Roman monuments can be found in Nepal $[20,21]$, thus, to fulfill the research gap, seismic vulnerability analysis based on field observations and finite element modeling are needed. Despite the grave importance in understanding the vulnerability of Greco-Roman monuments, field tests, numerical modeling, detailed assessments, and retrofitting frameworks of existing Greco-Roman buildings are scarce, if not absent, in Nepal. Due to the heritage as well as administrative values of such buildings, it is important to assess the vulnerability and level of seismic safety to ensure at least a life safety performance level is in place in the case of future earthquakes. This paper presents the damage scenario observed in the Bagh Durbar monument after the Gorkha earthquake. The field tests and finite element analysis are presented and a retrofitting framework for each vulnerable/damaged component is proposed as well.

\section{Materials and Methods}

The original construction of Bagh Durbar (Tiger Palace) is believed to have occurred in 1805 by the then Prime Minister Bhimsen Thapa who was replacing a small house constructed by his father. The original construction covered an area of $61049 \mathrm{~m}^{2}$; however, present-day Bagh Durbar is now limited to $2933 \mathrm{~m}^{2}$. The palace is located $\left(27^{\circ} 41^{\prime} 34.58^{\prime \prime} \mathrm{N}, 85^{\circ} 19^{\prime} 28.04^{\prime \prime} \mathrm{E}\right)$ in the central Kathmandu valley. The building was renovated by Bir Shamsher in 1885 and was reconstructed after the 1934 earthquake, which destroyed the monument [21]. Present-day Bagh Durbar (Figure 1), which is being used as the Kathmandu metropolitan city office, was constructed after the 1934 earthquake and was slightly altered from the Greco-Roman style by Juddha Shamsher and his son Hari Shamsher. The building has a rectangular combination of components with a central courtyard. The floors plans depict massive wall thickness and geometrically irregular constructions at several locations of the building. 


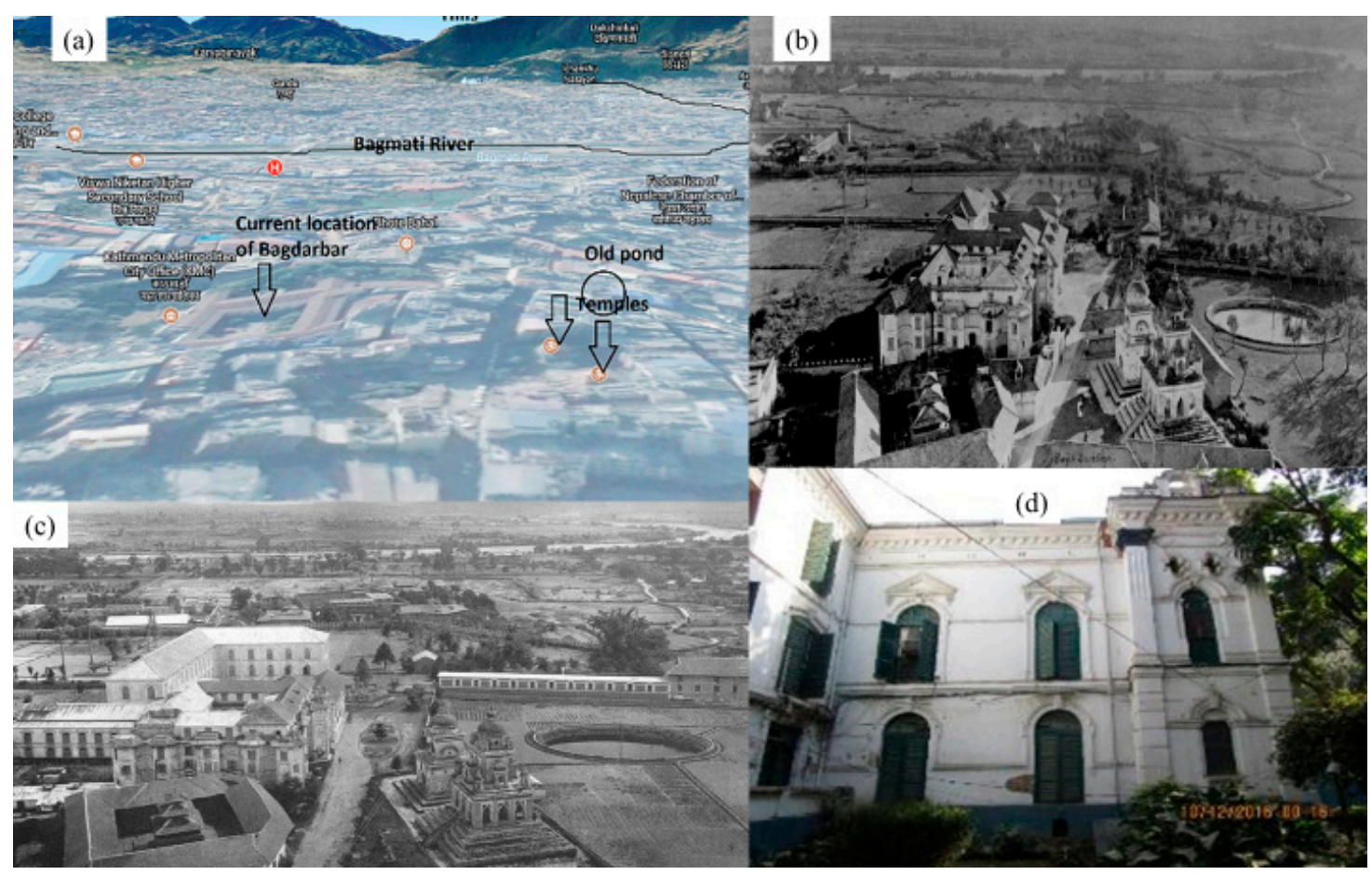

Figure 1. (a) Location of Bagh Durbar (b) old Bagh Durbar (picture credit: Madan Pustakalay, Lalitpur), (c) changes in construction and neighborhood in Bagh Durbar area (picture credit: Madan Pustakalay, Lalitpur), (d) present day facade of Bagh Durbar.

The building is situated in the plain terrain of central Kathmandu and is a load-bearing masonry building. The building is a three-storied Greco-Roman construction; however, there are only two stories in some locations with higher story heights. The vertical configuration is generally regular, and the plan configuration has some projections. The total plinth area of the building is $8564 \mathrm{~m}^{2}$. The thickness of most of the interior, as well as exterior walls, is 850 to $900 \mathrm{~mm}$ on the ground floor, 800 $\mathrm{mm}$ on the first floor, and $750 \mathrm{~mm}$ on the second floor, whereas the west extension of the building has a wall thickness of $650 \mathrm{~mm}$. Several interior walls provided with timber and aluminum partitions in the building were added later, thus, the present-day form of Bagh Durbar is not the same as the one constructed in 1935. The walls were constructed as brick masonry walls in mud-mortar and the floor structure was mixed with timber joists, and a jack arch with a steel I-beam in the original construction. The foundation was provided up to the depth of $\sim 3 \mathrm{~m}$ by the soling of brick bats in Surkhi mortar (mainly lime and brick powder). At the plinth level, damp proofing course of Surkhi, having $100 \mathrm{~mm}$ thickness, was observed during the excavation. However, a nearby deep borehole depicts that the upper $25 \mathrm{~m}$ depth is comprised of coarse-grained sand and clay mix. In between $25 \mathrm{~m}$ to $210 \mathrm{~m}$ depth, black carbonaceous clay (Kalimati formation) is present. From $210 \mathrm{~m}$ to $244 \mathrm{~m}$, clayey sand is dominant in the area where the monument is located.

The building is constructed mostly from traditional local materials including some standard rolled steel sections and cast iron. The foundation of the building comprises stepped brick walls. The walls were mostly brick masonry in mud mortar; whereas, a few walls constructed later were brick masonry in cement mortar as well. The wall thickness varied per the story. Surkhi plaster was provided to the exterior walls of the monument and the interior walls were plastered with mud plaster. Cement plaster was also found in some locations that were repaired later. The corridors and a few rooms of the building were provided with a timber floor structure and brick tile finishing. Most of the rooms were provided with steel I-beams with jacked brick arches and brick tile finishing. Some of the rooms have a timber floor structure and timber plank finishing as well. The roof of the building was provided with corrugated iron sheets and timber trusses were provided to support the roof. The ceiling of the 
building has decorative metal sheets with cornices in the halls; whereas, some other rooms have a timber false ceiling. Although the structure is a load-bearing structure, some brick columns were found in the large halls, above which a timber-girder and flooring system was provided. During the field study, a timber flooring system, timber roofing system, and floor system of a jacked brick arch with steel I-beam, were observed at various locations of the monument.

\section{Overview of the Damage}

According to the Department of Urban Development and Building Construction (DUDBC), government of Nepal vulnerability guidelines [22], the expected damage is grade-4 in case of an intensity IX earthquake, which demands appropriate interventions to be provided to assure adequate seismic safety in the case of strong to major earthquakes. Some observed deficiencies leading to the vulnerability of the structure are summarized as follows:

- Irregular building shape in plan (courtyard with wings, unequal bay-width) and room shape (long-rectangular and inclined)

- Story height is more than $3 \mathrm{~m}$, and the building is a three-storied brick in mud-mortar construction

- Outside walls/corridors are relatively long $(>10 \mathrm{~m})$

- Lack of vertical reinforcement in the walls, corners, and junctions

- Lack of horizontal bands, corner-stitch, and gable bands in the structure

- Flexible floors with variation in the floor-system and floor levels without effective bracing

These features of the building are reflected in the outcomes of the post Gorkha earthquake field reconnaissance reports. In fact, the monument suffered major structural and non-structural damages: most of the walls sustained slight structural damage; very few walls were heavily damaged without a risk of collapse of the whole structure; some floors were collapsed due to deteriorated timber joists; insignificant out-of-plane deformation was in very few walls, and some corners were separated. Similarly, the non-structural damage in the structure can be described as plaster delamination and collapse of some ceilings and floors (mainly due to deteriorated timbers).

The non-structural damage can be categorized as "Moderate" and structural damage can be depicted as "Slight" which yields the overall damage grade-2 (moderate) per the EMS-98 scale of damage grading [23]. Nevertheless, it is worth noting that intrinsic characteristics of the building and its value from an architectural standpoint made unrealistic the possibility of achieving immediate occupancy performance of the building under design as suggested by the Nepal Building Code (NBC)-105 [24], according to the seismic classification of the site. As the monument was constructed before the inception of design codes of practices, as well as by-laws, no seismic considerations were inputted during the construction, which led to the building being vulnerable in case of moderate to strong earthquakes, to which the codal provisions were formulated. Therefore, restoration of damaged components must be combined with seismic upgrading interventions capable of ensuring increased seismic performance and therefore preserving the monument. In this sense, the design process complies with relevant rules provided for architectural and historical heritage in some European countries (i.e., Italy), where specific guidelines have been released in recent years to combine property safety and conservation of monuments (e.g., [25]). Details of intervention and Finite element (FE) analysis after the introduction of retrofit design are presented in the following sections. Main damage locations are represented by uppercase letters in Figure 2 and the field evidence is presented in Figures 3-6. Figure 6a shows the damage led by the higher deflection which caused the corner separation and damage to the arch. Damages were mainly noted in terms of shear damage and corner separation. 


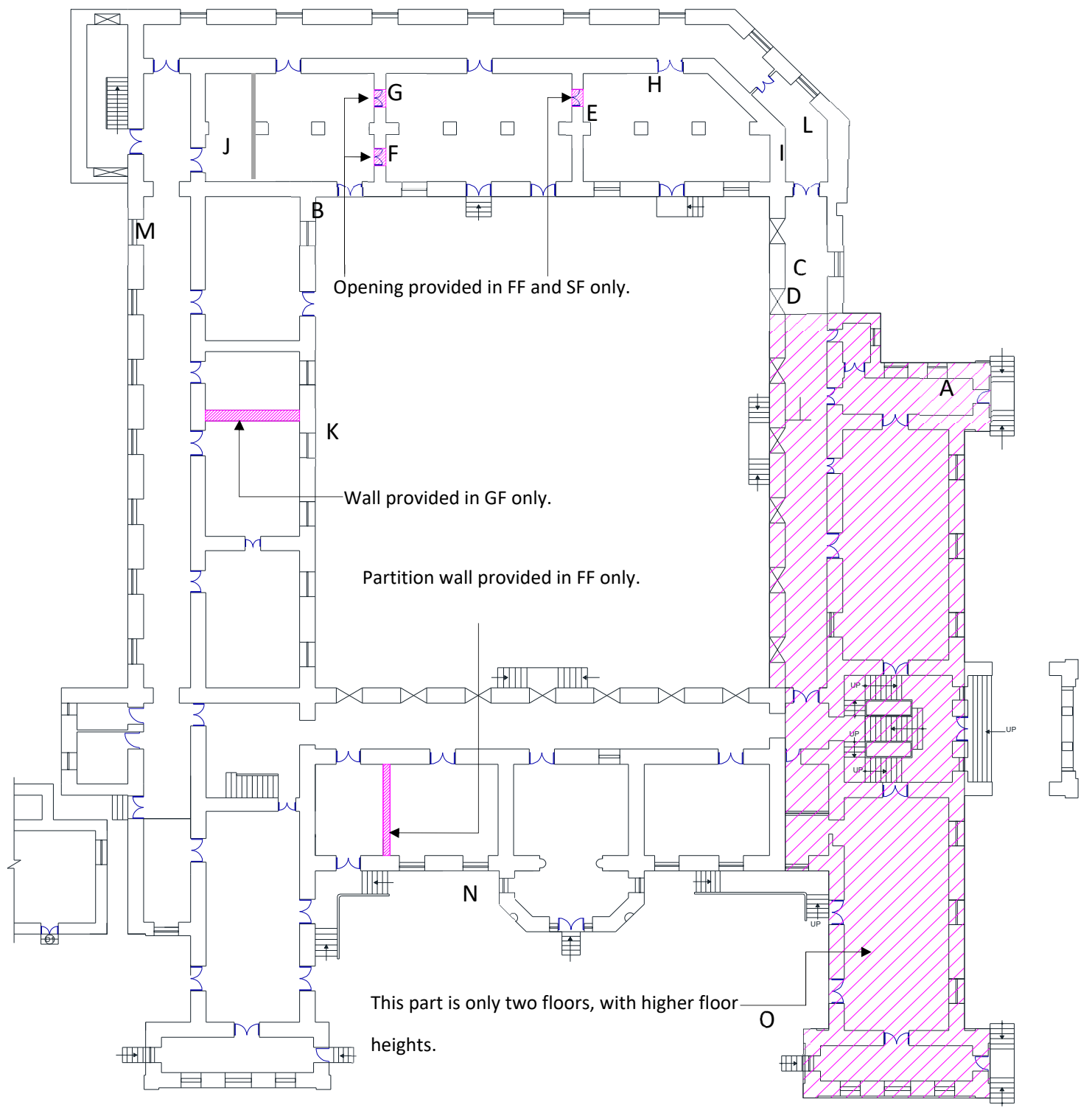

Figure 2. Major damage locations in the monument (capital letters represent the damage mechanisms as shown in Figures 3-6). In the figure, GF, FF, and SF respectively represent the ground floor, first floor, and the second floor. 

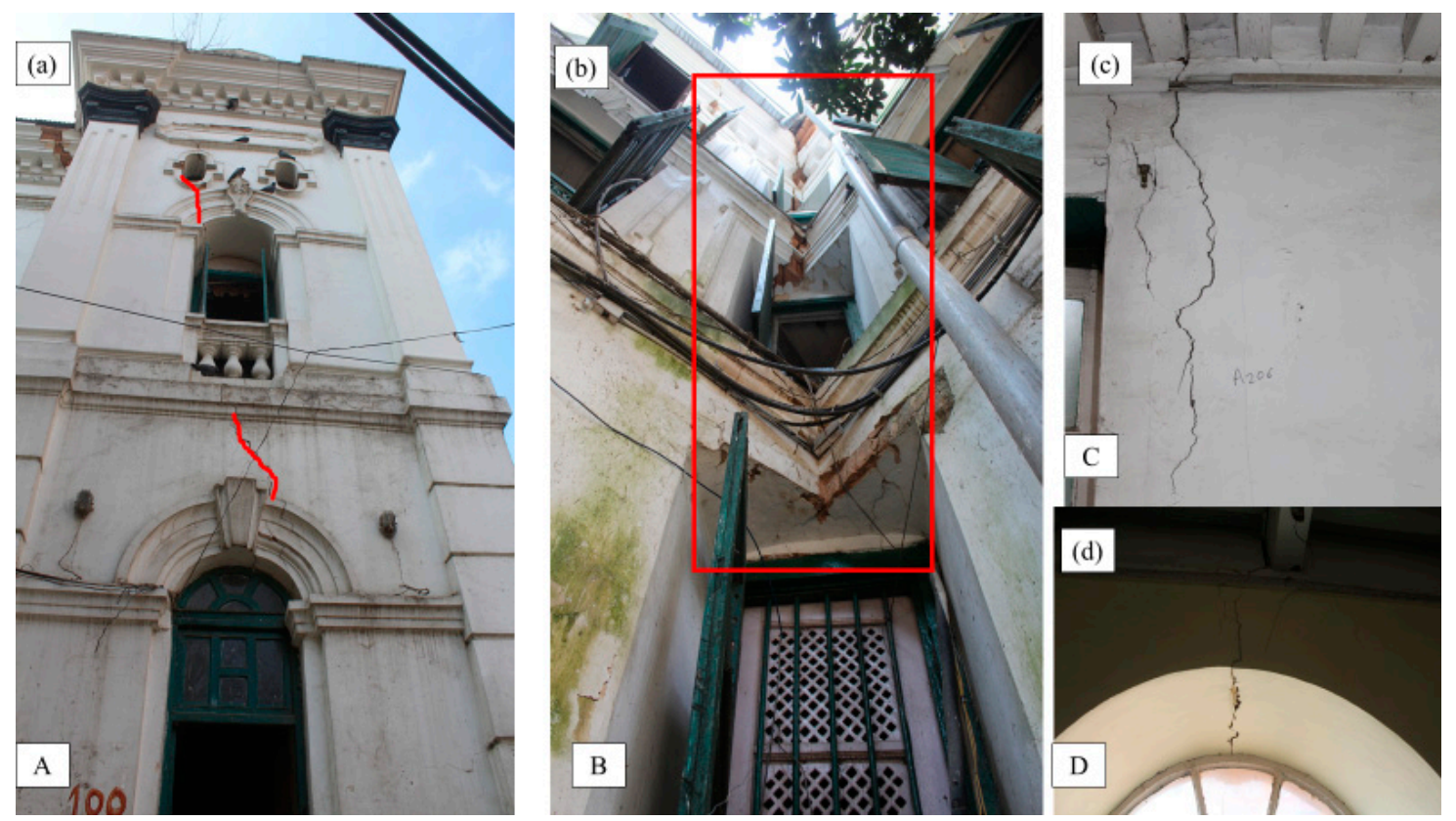

Figure 3. Local damages in the monument (a) damage above the crown of arches, (b) corner damage at the junction of north and west lounge, (c) vertical crack, (d) crown damage (uppercase indications at the bottom of the structures are the location indications as shown in Figure 2).
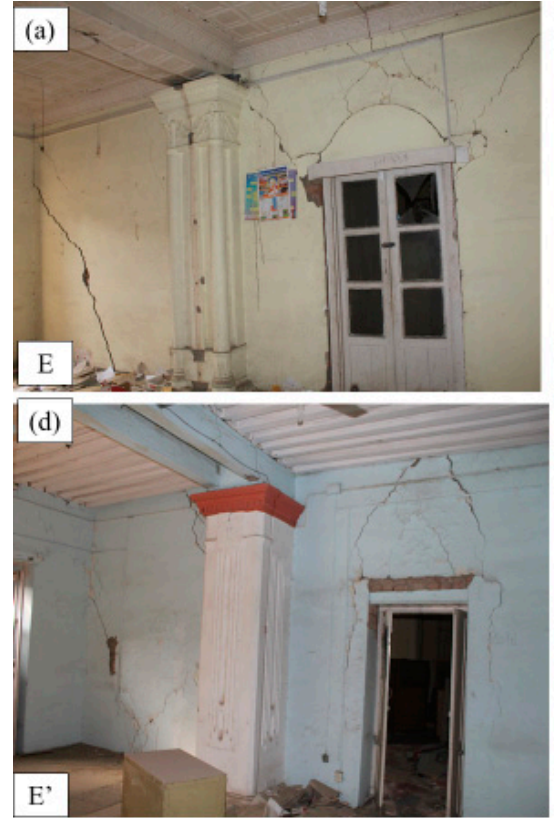
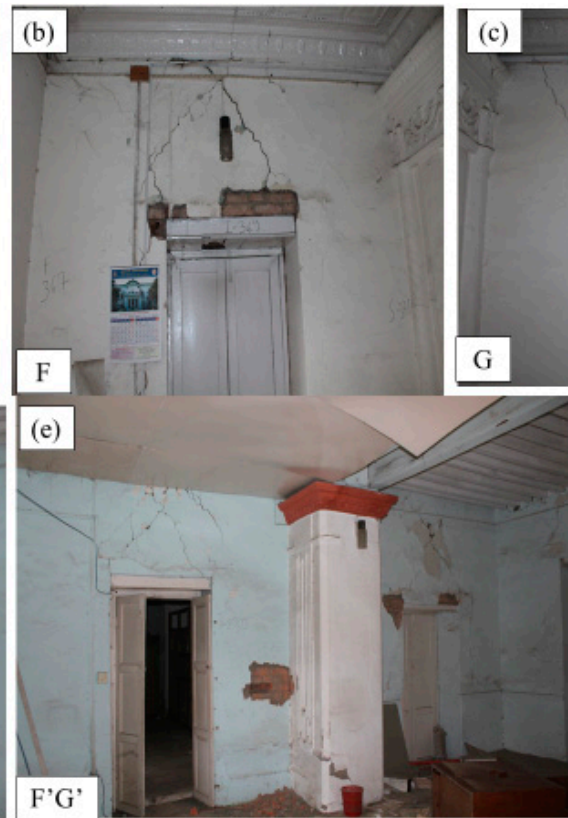
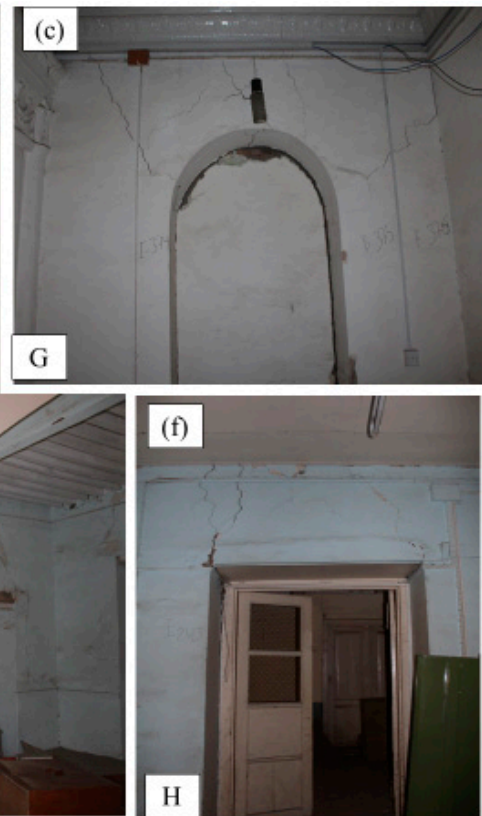

Figure 4. Local damages in the monument (a) diagonal cracks on cross-wall, (b) damaged wall above the opening, (c) damage above the crown of the arch on cross wall, $(\mathbf{d}-\mathbf{f})$ damages around the openings (uppercase indications at the bottom of the structures are the location indications as shown in Figure 2). 

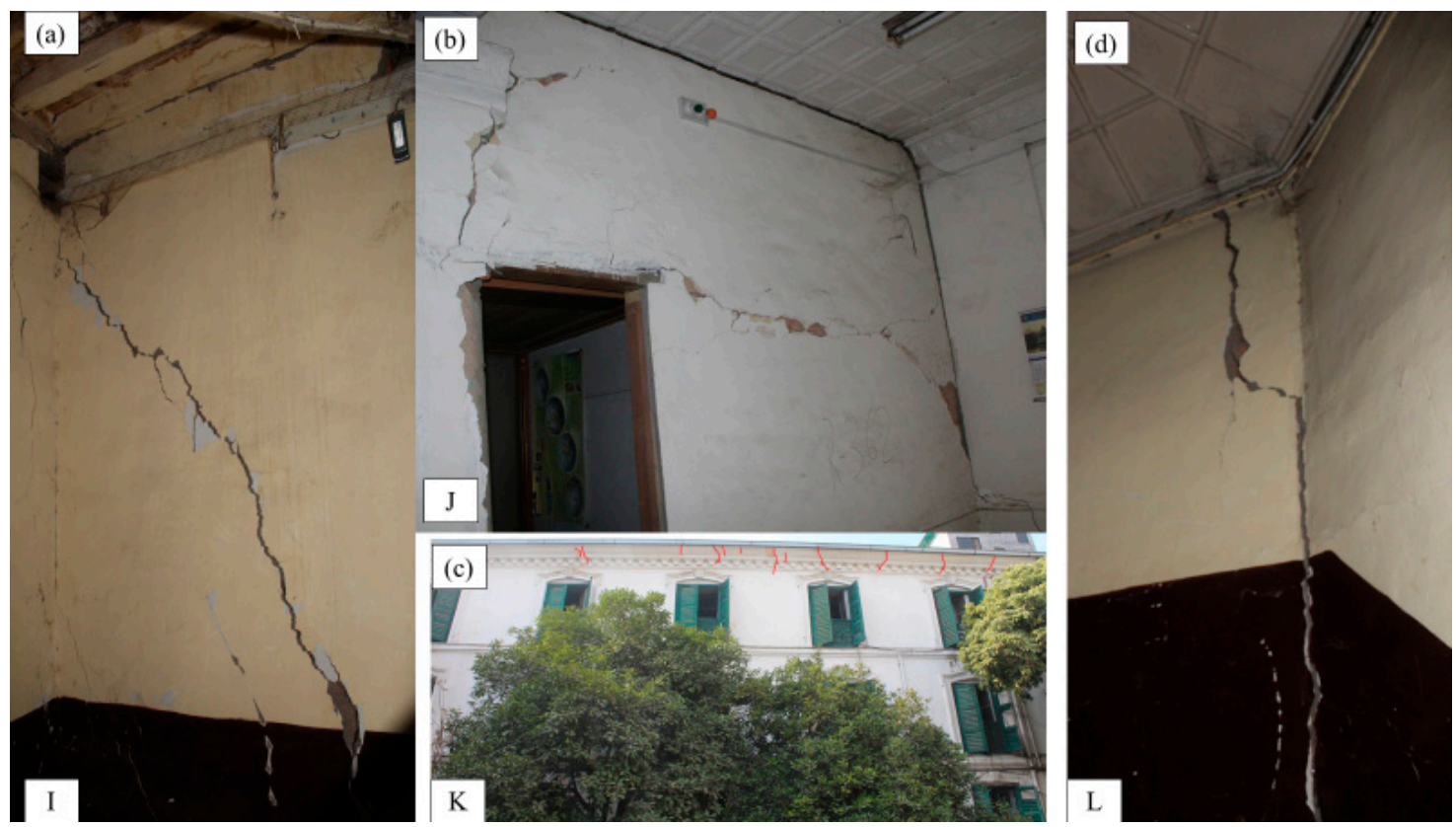

Figure 5. Local damages in the monument (a) diagonal crack on the third-floor wall, (b) horizontal and vertical cracks beside the opening, (c) exterior wall damage at the top floor, (d) corner damage (uppercase indications at the bottom of the structures are the location indications as shown in Figure 2).
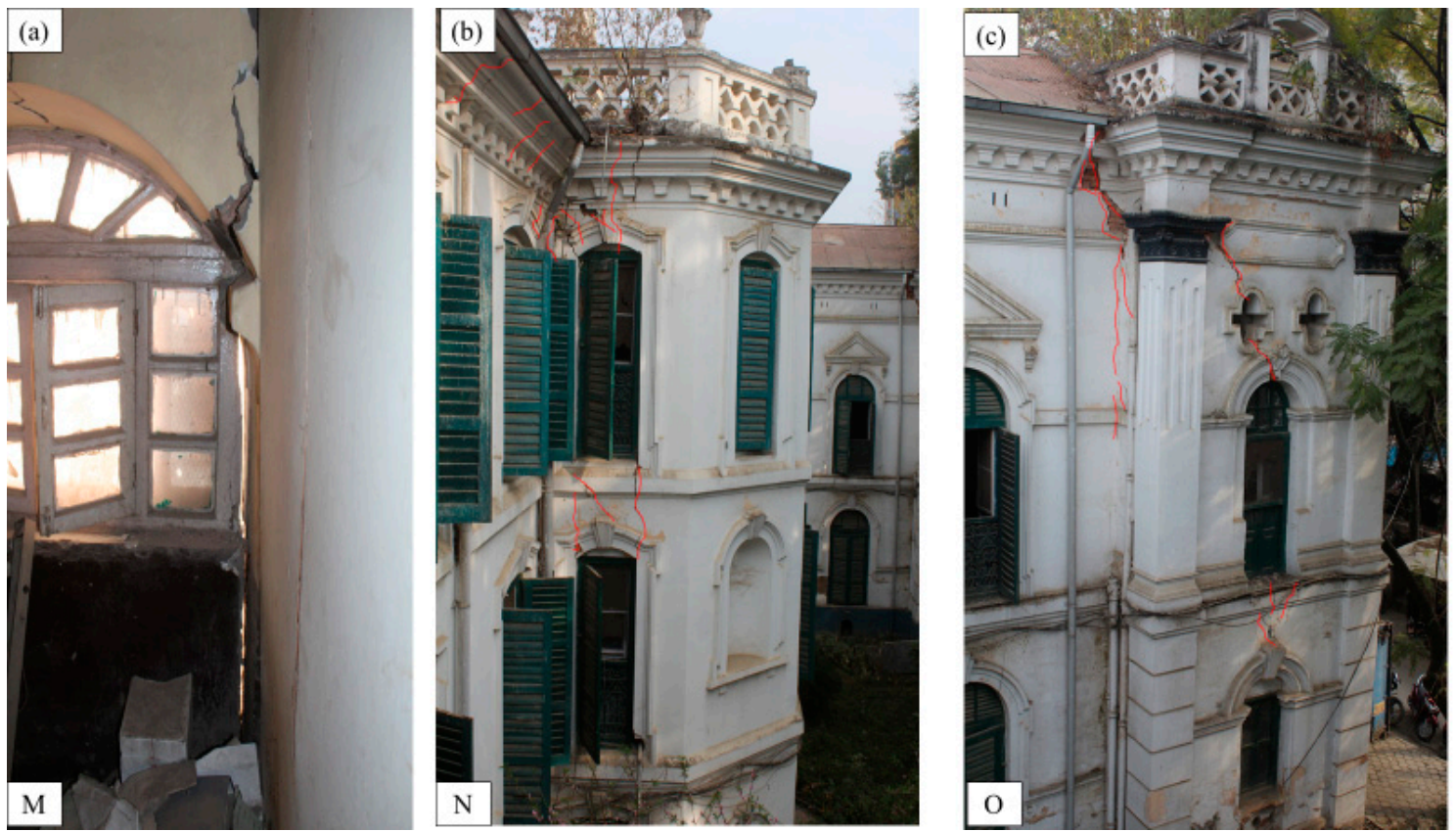

Figure 6. Local damages in the monument (a) corner damage, (b) corner damage and crack propagation in the projection part, (c) cracks developed above the arch. In figure, uppercase indications at the bottom of the structures are the location indications as shown in Figure 2.

\section{Structural Assessment}

\subsection{Qualitative Evaluation}

Rapid visual screening identifies potential deficiencies in a building based on checks made with the help of standard checklists, and it often relies on the experience of the personnel in the same field. The qualitative evaluation was conducted using the Tier-1 evaluation of Federal Emergency 
Management Agency (FEMA-310) [26] and qualitative structural assessment per the Department of Urban Development and Building Construction (DUDBC), Government of Nepal, guidelines [22]. Qualitative assessment of the building was conducted for the building system, lateral load resisting system, diaphragms, and geological site. For each evaluation aspect, compliance and non-compliance were noted based on the field observations. The shape of the building, proportion in the plan, story height, number of stories, unsupported wall length, openings in walls, and wall cracks were observed as non-compliant. Meanwhile, foundation, sloping ground, plumb line, wall thickness, wall core, height of the walls, position of openings, load path, vertical discontinuities, mass, masonry unit, and masonry lay-up were found to be compliant for the building system. Similarly, for the lateral force resisting system, vertical reinforcement, horizontal band, shear stress, and corner stitch were found to be non-compliant. In the case of diaphragms, all three components, diagonal bracings, lateral restraints, and unblocked diaphragms, were found to be non-compliant. For the geological site, area history and slope failure were compliant; whereas, liquefaction was non-compliant at the site. Based on the qualitative assessment, detailed seismic assessment of the monument was suggested. To accomplish this task, several in-situ tests were conducted along with the finite element analysis. As heritage and monuments are the types of buildings that require special attention during every intervention, understanding the state of the building has great importance [27-29]. To this end, field tests and investigations are of the utmost priority as reconstruction may not be a plausible solution in most of the cases. It is also very important to note that the properties of construction materials demand tests as there would be substantial changes in the manufacturing process in due course, which makes field investigations and in-situ, as well as laboratory, tests more pivotal.

\subsection{Material Characterization}

Owing to the fact that the allocation of material properties in modeling is likely to be suffered from the uncertainties, in-situ tests were performed to obtain the material properties when possible. Push shear tests were conducted in five different locations: one on the ground floor, two on the first floor, and two on the second floor. Using the FEMA-273 guidelines [26], the tests were carried out and then analyses were done. For further details regarding the push shear test procedure, the reader is directed to FEMA-273 [26]. The average shear strength at lintel-level of masonry wall on ground, first, and second floor was estimated to be $0.1,0.1$, and $0.08 \mathrm{MPa}$, respectively. Brick units from three different locations of the structure were also tested. Large scale intervention during the assessment was not possible. thus, only three brick units from the existing wall were tested. The brick samples were taken out carefully by scrapping the mortar around it. The samples were tested in the laboratory with the standard procedure. The dimensions of the brick samples were taken and averaged first. Thereafter, cement mortar was provided to smoothen the surface and curing was done as per standard practice. The load was applied in the direction of the depth in the universal testing machine. The load was gradually applied, and finally, the compressive strength was estimated with the help of the load and the area of the specimen. Three bricks considered for compressive strength test reflected the compressive strengths as 6.63,1.14, and 5.30 MPa. One of the bricks showed relatively lower strength than the other specimen. This is probably due to random manufacturing process of that time and furthermore, the baking process might have been compromised too. Test results highlight that there is wide discrepancy in the strength of the brick units at various locations of the structure. Visually, the bricks were good, but the strength was not per the expectations and initial estimation. The average strength of the brick was found to be $4.3 \mathrm{MPa}$ which can be classified as the lower bound standard of 3.5 MPa grade brick.

The mortar in most of the parts of the structure was found to be intact. The compressive strength of mud-mortar is generally very low, and estimation of exact compressive strength is challenging job; however, standard penetrometer test was conducted on mud-mortar at several locations to estimate and compare compressive strength of the mortar. The compressive strength was obtained in the range of 0.1 to $0.32 \mathrm{MPa}$ with an average of $0.18 \mathrm{MPa}$ for the structure. Brick bond was observed in the 
damaged portion and all locations without plaster. English bond was found in all tested and exposed locations of the building. Pit excavation test was also carried out to identify the properties of the footing. The test highlighted that there was no significant damage in the footing level, except hairline cracks in few brick units. The summary of the test results is presented in Table 1.

Table 1. Summary of material test results.

\begin{tabular}{|c|c|c|}
\hline Parameter & Test Results & Remarks \\
\hline Shear strength of masonry wall & $\begin{array}{l}0.1 \mathrm{MPa}, 0.1 \mathrm{MPa} \text {, and } 0.08 \mathrm{MPa} \\
\text { for ground floor }(\mathrm{GF}) \text {, first floor } \\
(\mathrm{FF}) \text {, and second floor (SF) }\end{array}$ & $\begin{array}{l}\text { Two tests were carried out on each } \\
\text { floor and the average value was } \\
\text { taken. Due to lesser dead load, the } \\
\text { value was low at the top floor, } \\
\text { while because of slight damp } \\
\text { conditions, the value did not } \\
\text { increase on ground floor. }\end{array}$ \\
\hline Compressive strength of brick & $\begin{array}{l}6.63 \mathrm{MPa}, 1.14 \mathrm{MPa} \text { and } 5.3 \mathrm{MPa} \\
\text { for three units }\end{array}$ & $\begin{array}{l}\text { There was restriction in obtaining } \\
\text { more samples, thus, } 3.5 \mathrm{MPa} \\
\text { bricks were considered to match } \\
\text { the categorization. }\end{array}$ \\
\hline Compressive strength of mortar & $\begin{array}{l}\text { Varied from } 0.1 \mathrm{MPa} \text { to } 0.32 \mathrm{MPa} \\
\text { in } 11 \text { locations }\end{array}$ & $\begin{array}{l}\text { Though not accurate, a } \\
\text { penetrometer test was conducted } \\
\text { that gave an average strength of } \\
0.18 \mathrm{MPa} \text {. }\end{array}$ \\
\hline Wall core and bonding type & $\begin{array}{l}\text { All walls were solid } \\
\text { English bond was found }\end{array}$ & $\begin{array}{l}\text { All walls were identified to be } \\
\text { solid brick walls as observed at the } \\
\text { test and damage locations. }\end{array}$ \\
\hline Foundation & $\begin{array}{l}\text { Masonry strip footing with base } \\
\text { width of } 1700 \mathrm{~mm}\end{array}$ & $\begin{array}{l}\text { Excavation was done in two } \\
\text { locations. Stepping was found to } \\
\text { be done to increase the width of } \\
\text { footing at the base, increasing } 50 \\
\text { mm in width at each side at every } \\
150 \text {-mm depth. }\end{array}$ \\
\hline
\end{tabular}

\subsection{Analytical Modeling}

A three-dimensional finite element model was created in SAP2000 v.20 [30] based on the concept of homogenized wall materials assuming the building to be supported at the plinth level by hinges as shown in Figure 7. The hinge support assumption allows capturing the redistributed stress after formation of tension cracks near plinth, which is more realistic than the assumption of the fixed base analysis. Thin shell elements (iso-parametric 4-nodded and 3-nodded area elements) were used to model the structural masonry walls. Two-nodded frame elements (line elements) were used to model beams and timber joists in the floor and roof. Timber floors were modeled with thin shells equivalent to the provided timber planks that provided partial in-plane rigidity. The building has over 10,500 square meters of wall and floor area in the model that demands very high input in modeling and analysis of the structure. Further, the accurate assessment of material properties, accurate constitutive model of masonry element, and rigorous non-linear analysis are important for rational performance evaluation. Owing to the fact that nonlinearity characteristics of masonry play a dominant role in discrepancies that arise during nonlinear dynamic analysis, a detailed study regarding nonlinear properties of materials is needed. However, to do so, sophisticated facilities are needed, and such facilities are not available in Nepal. Thus, because of accurate damping characteristics, natural periods, Poisson's ratio, friction between different materials, and other parameters, a simplified modeling technique was adopted using a homogenized macro element for the wall modeling. 


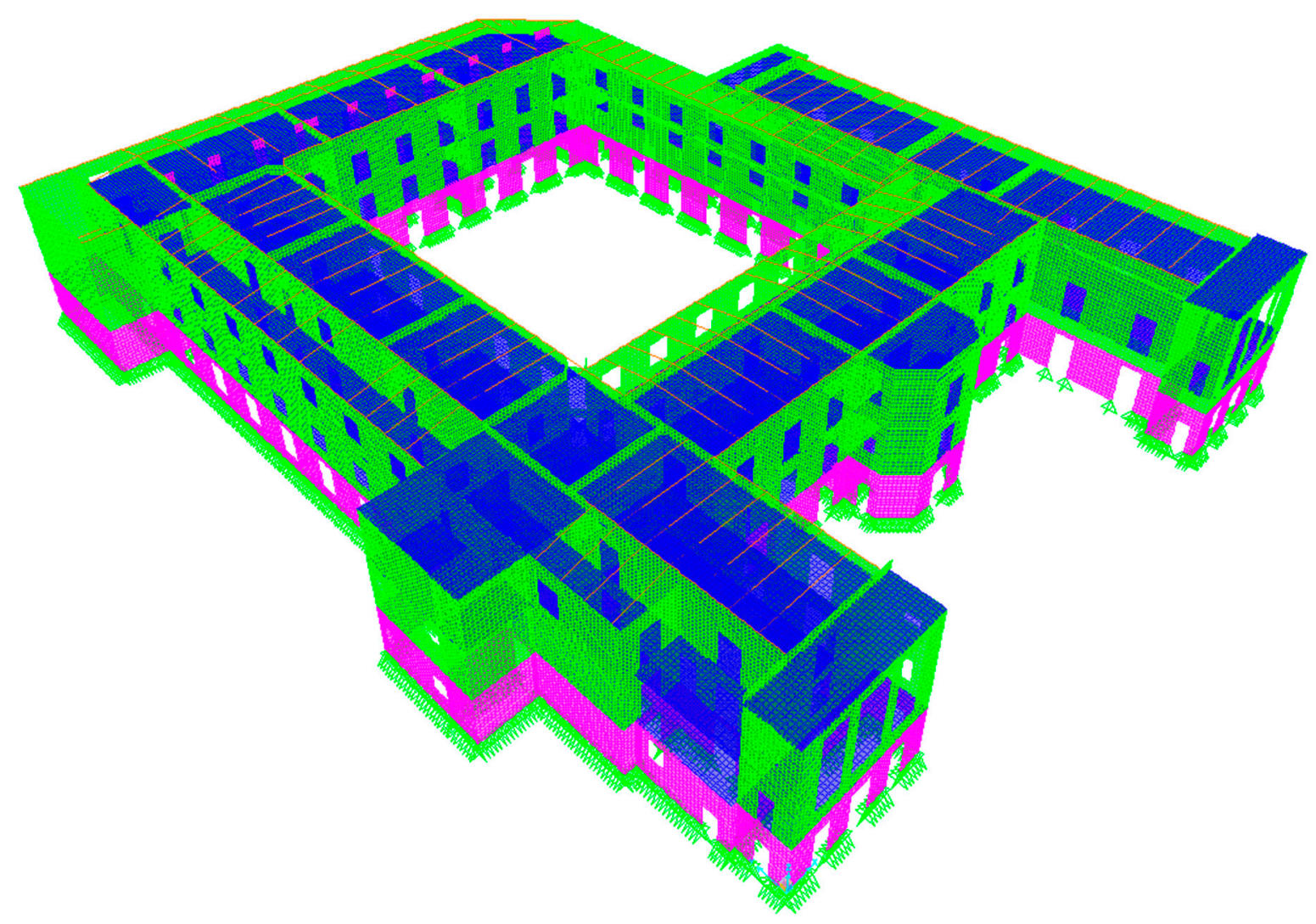

Figure 7. Three-dimensional finite element model of Bagh Durbar.

The mechanical characteristics of materials for modeling are based on laboratory tests, and related previous studies. As the minimum basic strength of masonry per the identified brick strength from tests and weakest mortar according to Indian Standard (IS) 1905:1987 is $0.25 \mathrm{MPa}$, that corresponds to the average compressive strength of $1 \mathrm{MPa}$, and the same strength was adopted in this study. Three specimen masonry prisms tested in Nepal (personal communication with Ram Udar Yadav) for similar construction material affirmed the adopted value, as the test results showed a compressive strength of nearly $1 \mathrm{MPa}$. The Young's modulus of masonry was taken as $550 \mathrm{MPa}$, which is calculated as 550 times the average compressive strength of masonry as recommended by Indian Standard 1893 (part 1) and 2016. The Poison's ratio of masonry was taken as 0.2. In the case study building, the height to width ratio of brick units is less than 0.75 ; slenderness ratio of walls is below 6 ; and no portion of the wall has an area lower than $0.2 \mathrm{~m}^{2}$; thus, per the IS 1905:1987 [31] recommendations, the permissible stress in masonry for design equals basic compressive strength of masonry, which is one fourth of the average compressive strength of masonry (1 MPa). Several studies (e.g., [27-29]) highlight the necessity of non-destructive tests and material identification in order to predict the actual behavior of complex aggregate buildings and historical constructions. Thus, laboratory tests are required to characterize such properties.

For performance assessment, the building was evaluated against standard requirements as suggested by the Nepal Building Code (NBC). A live load of $2.5 \mathrm{KPa}$ to $4 \mathrm{KPa}$ was considered as per IS 875 (part 2). The analysis was carried out for the design earthquake considering the base shear coefficient of 0.384 . Similarly, the base shear coefficient for the retrofitted model was adopted as 0.301 , as recommended by the NBC-105 [28]. The values of basic seismic coefficient (C) (corresponding to a low natural period of about $0.12 \mathrm{~s}$ ), seismic zone factor (Z) (for Kathmandu), and importance factor (I) (considering large number of occupants), were taken as $0.08,1.0$, and 1.2, respectively. The value of structural performance factor $(\mathrm{K})$ was taken as 4 and 3.14 for existing and retrofitted models corresponding to unreinforced masonry and masonry with horizontal and vertical bands. As the 
NBC recommends the value of structural performance factor for unreinforced masonry only, the structural performance factor for relatively ductile masonry with horizontal and vertical confining members was considered per common practice taking a slightly higher value, owing to the fact that the confinements are externally provided and slightly inferior compared to monolithically constructed confining elements. To this end, response spectrum analysis was performed considering the response spectrum as suggested by the Indian Standard Code [32]. Different response modification factors as suggested by the Indian Standard Code [32] were adopted for non-retrofitted and retrofitted models to match the base shear recommended by the NBC. A comparative plot of the Indian Standard response spectrum for soft soil is presented along with the three components response spectra for the recorded accelerograms nearby the building (Figure 8). As shown in Figure 8, the vertical component of the accelerogram showed that a higher response was observed at a low period, which surpassed the horizontal components. This is a unique response spectrum for the far-field records, thus, some of the damage to the non-structural members like the partition walls and damage to the upper stories might be attributed to strong vertical shaking. As highlighted by Figure 8, the horizontal components of the response spectra were clearly below the design spectrum for the structural period of $0.12 \mathrm{~s}$.

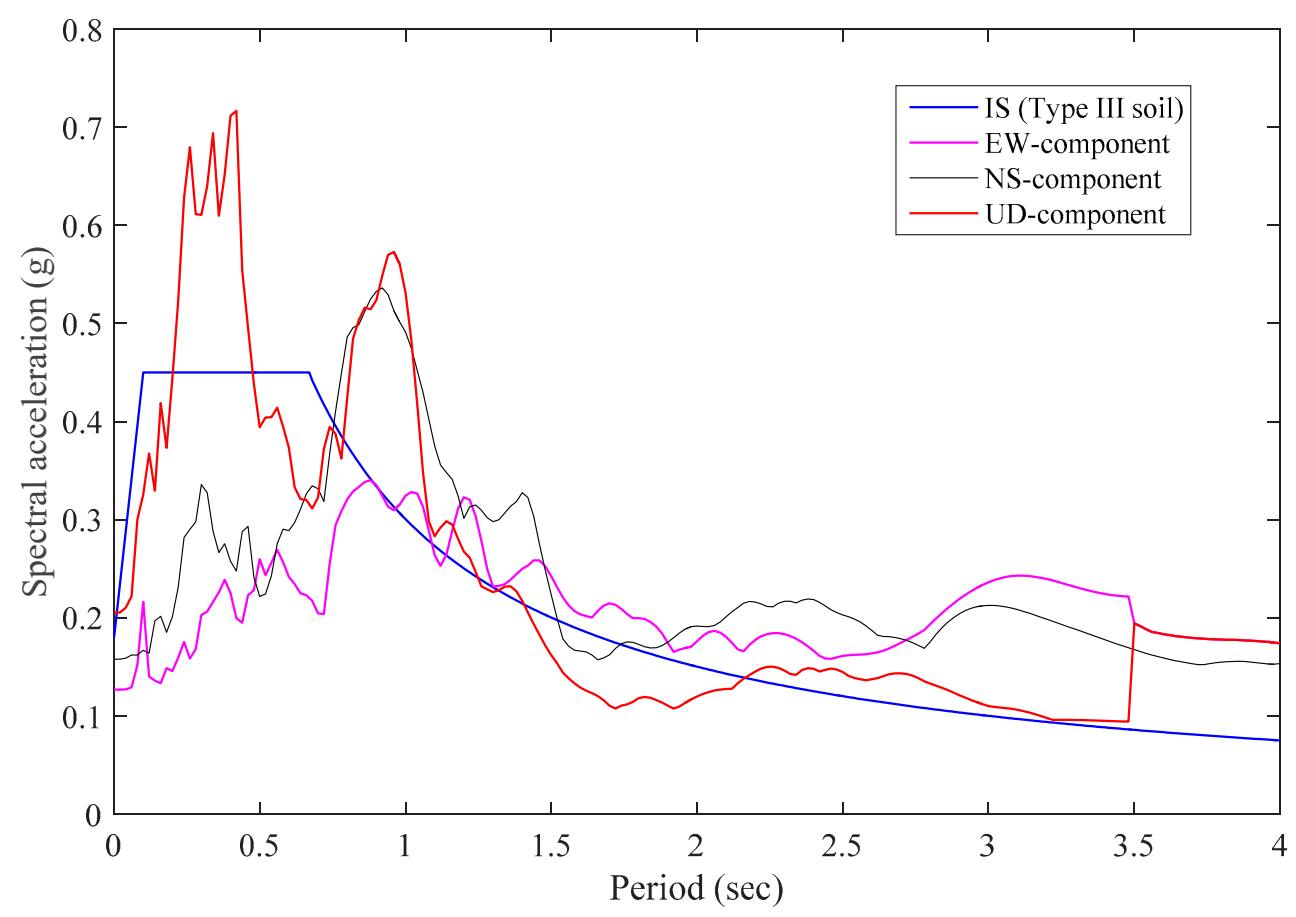

Figure 8. Response spectra of the recorded accelerogram at the Department of Mines and Geology plotted along with Indian Standard code response spectrum for soft soil. In the figure, EW indicates the east-west component of acceleration, NS indicates the north-south component of acceleration, and UD indicates the vertical acceleration component.

Before the detailed analysis of the structure, average stress on the wall at the ground floor was checked. The simplified average stress check showed that the average shear stress demand is about two times greater than the in-plane shear capacity of the mud-mortar walls, which indicates the need for strengthening of the structure. Also, the vertical stress for the dead load and full live load is found to exceed the permissible compressive strength of $0.25 \mathrm{MPa}$, but was found within the average compressive strength of $1 \mathrm{MPa}$. This fact indicates that even at minor shaking or disturbance, some parts of the masonry may be damaged. Tensile and compressive stresses due to rocking of the building were found to be negligible in the structure due to the large plan area. However, rocking of individual walls induced additional tension and compression, which were investigated in the detailed analyses. Stresses in individual wall piers of the structure were analyzed by finite element modeling. The 
performance of each masonry wall was evaluated for the most critical combination of loads per the Nepal Building Code.

The modal analysis highlighted that the first four modes contributed significantly, leading to $60 \%$ mass participation in the $x$-direction and $50 \%$ in the y-direction. Mass participation of $85 \%$ was achieved by processing 44 modes. The period of the structure was $0.295,0.292,0.276$, and $0.272 \mathrm{~s}$, respectively, in the first four modes. After the seventh mode, mass participation was less than $5 \%$ for both directions in any individual mode except the 12th mode which showed $6 \%$ mass participation in the y-direction. A summary of significant mass participation, along with the period of each mode, is presented in Table 2. Figure 9 shows the mode shapes for the first four modes. The first mode reflects that the walls in the western portion experienced higher deformation in the first mode (Figure 9a). The second mode shows that higher deformation was concentrated in the east side of the aggregate in the narrow corridor (Figure 9b). Similar damage occurrence was also noted in the walls of the east side of the aggregate as shown in Figure 5. The arching of the north side of the aggregate should have caused in-plane damages to the cross-walls as shown in Figure 5. The damage mechanisms are represented in Figure 4 by uppercase letters E, F, and $\mathrm{G}$ on the third floor and, $\mathrm{E}^{\prime}, \mathrm{F}^{\prime} \mathrm{G}^{\prime}$, and $\mathrm{H}$ on the second floor. The third mode depicted that the projection in the south-east direction experienced the largest deformation as shown in Figure 9c. Consistently, in-plane damage as shown in Figure 6c was observed due to the earthquake which is indicated by the uppercase letter ' $\mathrm{O}$ ' in Figure 2. As shown in Figure 9d, the fourth mode shows higher deformation in the south-west projection of the structure. Consistently, the damage also occurred in the same wall due to the Gorkha earthquake.

Table 2. Summary of modal mass participation in $\mathrm{x}$ - and y-direction in the first 15 modes.

\begin{tabular}{|c|c|c|c|}
\hline Mode & $\begin{array}{l}\text { Period } \\
\text { (sec) }\end{array}$ & $\begin{array}{l}\text { Modal Mass Participation } \\
\text { Ratio in x-direction }\end{array}$ & $\begin{array}{l}\text { Modal Mass Participation } \\
\text { Ratio in y-direction }\end{array}$ \\
\hline 1 & 0.295 & 0.450 & 0.071 \\
\hline 2 & 0.292 & 0.054 & 0.046 \\
\hline 3 & 0.276 & 0.087 & 0.170 \\
\hline 4 & 0.272 & 0.000 & 0.190 \\
\hline 5 & 0.249 & 0.025 & 0.038 \\
\hline 6 & 0.242 & 0.014 & 0.051 \\
\hline 7 & 0.228 & 0.001 & 0.060 \\
\hline 8 & 0.222 & 0.008 & 0.001 \\
\hline 9 & 0.200 & 0.050 & 0.006 \\
\hline 10 & 0.199 & 0.002 & 0.001 \\
\hline 11 & 0.198 & 0.001 & 0.007 \\
\hline 12 & 0.198 & 0.000 & 0.060 \\
\hline 13 & 0.187 & 0.011 & 0.015 \\
\hline 14 & 0.181 & 0.011 & 0.007 \\
\hline 15 & 0.167 & 0.001 & 0.008 \\
\hline
\end{tabular}




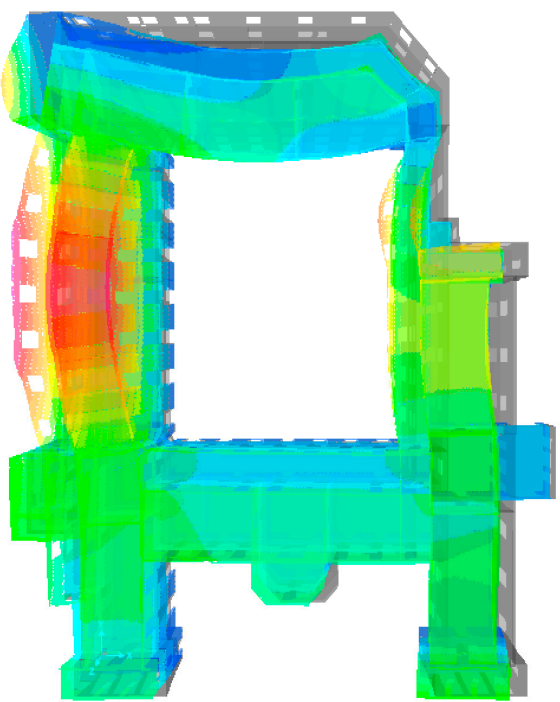

(a)

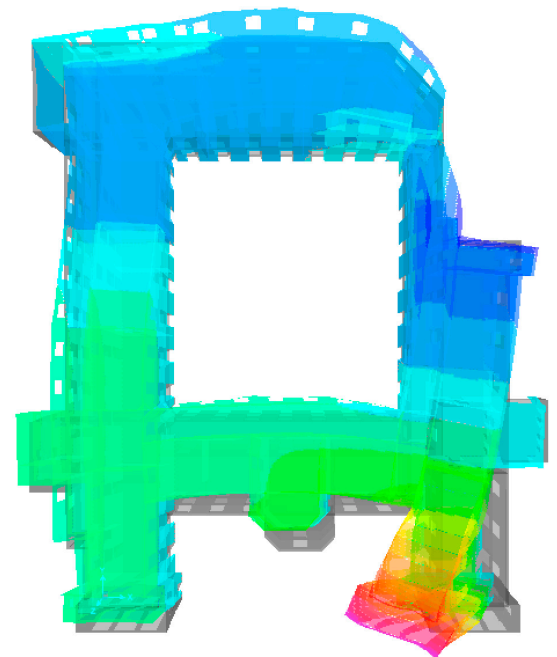

(c)
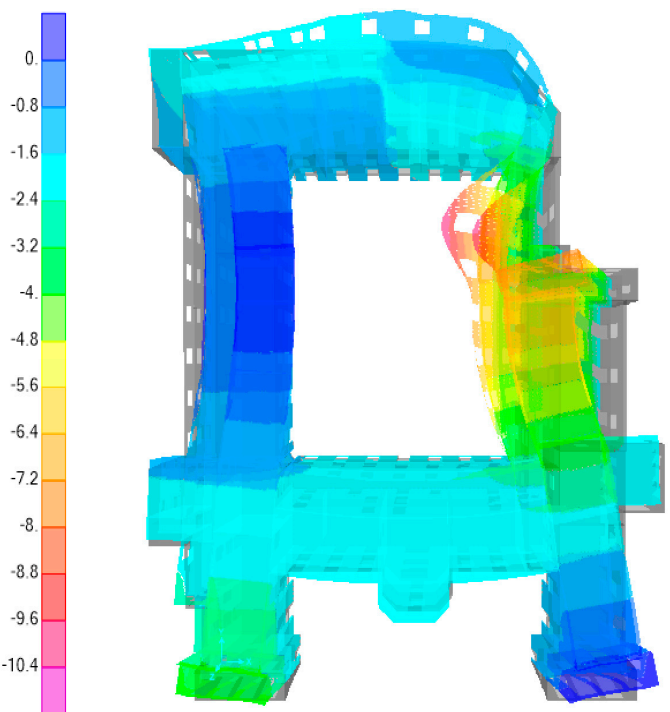

(b)
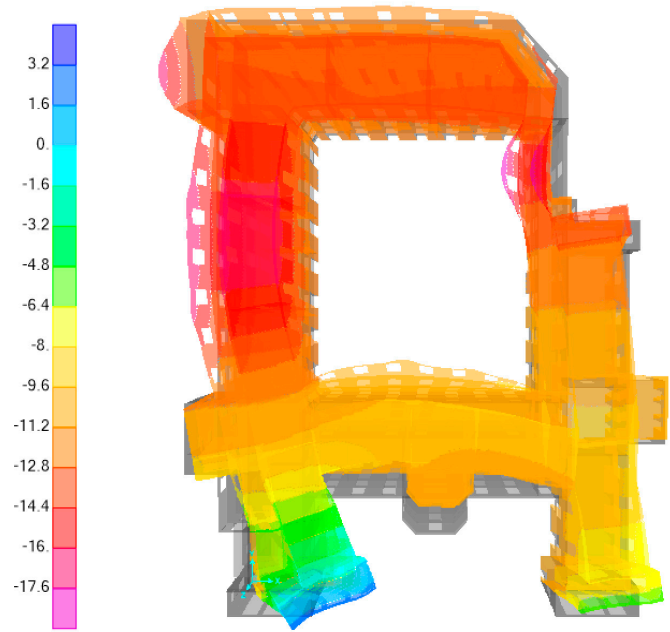

(d)

Figure 9. Deformed shape (a) mode 1 at the period of $0.295 \mathrm{~s},(\mathbf{b})$ mode 2 at the period of $0.292 \mathrm{~s}$, (c) mode 3 at the period of $0.276 \mathrm{~s}$, and (d) mode 4 at the period of $0.272 \mathrm{~s}$.

Stresses were checked for the wall sections accounting for different load combinations per NBC-105 [24] recommendations. For each wall, vertical and horizontal loads, as well as the moments in the two directions, were used to analyze the stresses. Compliance test results agree that the damage due to the Gorkha earthquake as the response spectrum analysis of the as-built model showed that $49 \%$ of the walls were non-compliant, indicating some level of direct tension. Similarly, $40 \%$ of the walls depicted non-compliance with permissible compression. However, $97 \%$ of the walls were found to be deficient in shear. As almost every wall demanded ductility enhancement and confinement, retrofitting was proposed for the monument as outlined in the following section.

\section{Design of Structural Restoration and Seismic Strengthening}

Method selection is a crucial step in providing interventions to monumental constructions. Based on the building typology and expected level of performance following the retrofitting, compliance with existing codes of practices, functionality requirements, cost constraints, availability and compatibility of retrofitting solutions, safety and serviceability of the structure, aesthetics, and cultural values, among others, were kept in mind during the selection of the method. With the aforementioned considerations, 
different strengthening options were compared. After several expert level consultations, retrofitting using reversible and traditional construction materials with steel plates were considered as the most rational and viable option, and analysis was done for the same. Traditional materials (or previously used materials) like Surkhi, lime, timber, and steel were selected for the interventions in most of the locations. In the meantime, reinforced concrete was not used in the design to preserve the morphology of the building. Herein, appropriateness in the use of steel sections was due to ease in installation as well as in removal or replacement of the retrofitted portions when required. The retrofitting framework developed for the Bagh Durbar monument is presented in Figure 10. The details of the bands, diagonal bracings, and timber joist end connections are respectively presented in Figures 11-13. As shown in Figure 11, the flexible floors are provided with floor level bracings to increase the floor rigidity. With a revised base shear after the interventions, which decreases significantly because of an increase in ductility of structure, the compliance of individual walls against shear resistance was increased appreciably and satisfied the design criteria as well. The global shear resistance of the structure, including provided sections, is at least two times greater than the overall demand which caters for localized high-stress demands. After retrofitting, a part of compression (under critical load) would be shared by vertical steels as well. As the design is based on permissible stress, average stress capacity of the existing wall and added steel elements would be higher, which provides the necessary safety margin.

A horizontal band of $300 \times 8 \mathrm{~mm}$ was designed to suffice the out-of-plane bending of the wall at the lintel level. Although the existing thickness of the wall makes it less vulnerable to out-of-plane instability, the bands simultaneously improve the integrity and ductility of the wall and the structure. Horizontal bands were also provided at the floor level using plates on the exterior face and ISMC-250 on the interior side. All horizontal bands were welded to vertical bands using a single bevel butt weld and extra lapping plate. Horizontal bands on both faces of the walls were connected by bolts and anchored to the wall. The total moment of resistance of the wall, together with bands, exceeded the out-of-plane moment of the wall from analysis under critical load combination; thus, the provided steel section is sufficient. Both I-beam with jack arch floors and wooden joist floors were made more rigid against in-plane deformation. For an I-beam with jack arch floor, ISMC-250 was placed at the interior face of all rooms and joined together as a box. Diagonal strips were welded to the underside of existing I-sections for satisfactory in-plane rigidity. The I-sections were connected to the floor band ISMC-250 as detailed in drawings.

For timber floors, since most of the visible timber in the floors had deteriorated, all flooring timber was replaced by seasoned timber with a strip of plastic damp-proof course underneath and related protection work, especially at the embedded length. Wooden floors were stiffened in-plane by the provision of two layers of timber plank flooring oriented in the perpendicular direction. Furthermore, wooden joists were connected to supporting walls by steel strips welded to the horizontal band on the exterior side of the wall for proper anchorage as detailed in Figure 13. The roof truss was observed to be displaced in some locations and some timber portions were damaged and deteriorated. The entire roof required dismantling and reconstruction. On average, $40 \%$ of the existing timber needed to be replaced and the rest could be reused with necessary protection works. Vertical bands were required to be extended up to the roof level. Gable band and roof band consisting of wooden joists were required to be placed and the roof truss required to be reconstructed per the existing design and detail. Then diagonal braces were needed between rafters and the rafters needed to be connected to the roof band using steel strips. Further, the roofing sheets required replacement by new corrugated galvanized iron (CGI) sheets and were anchored firmly to the roof truss. 


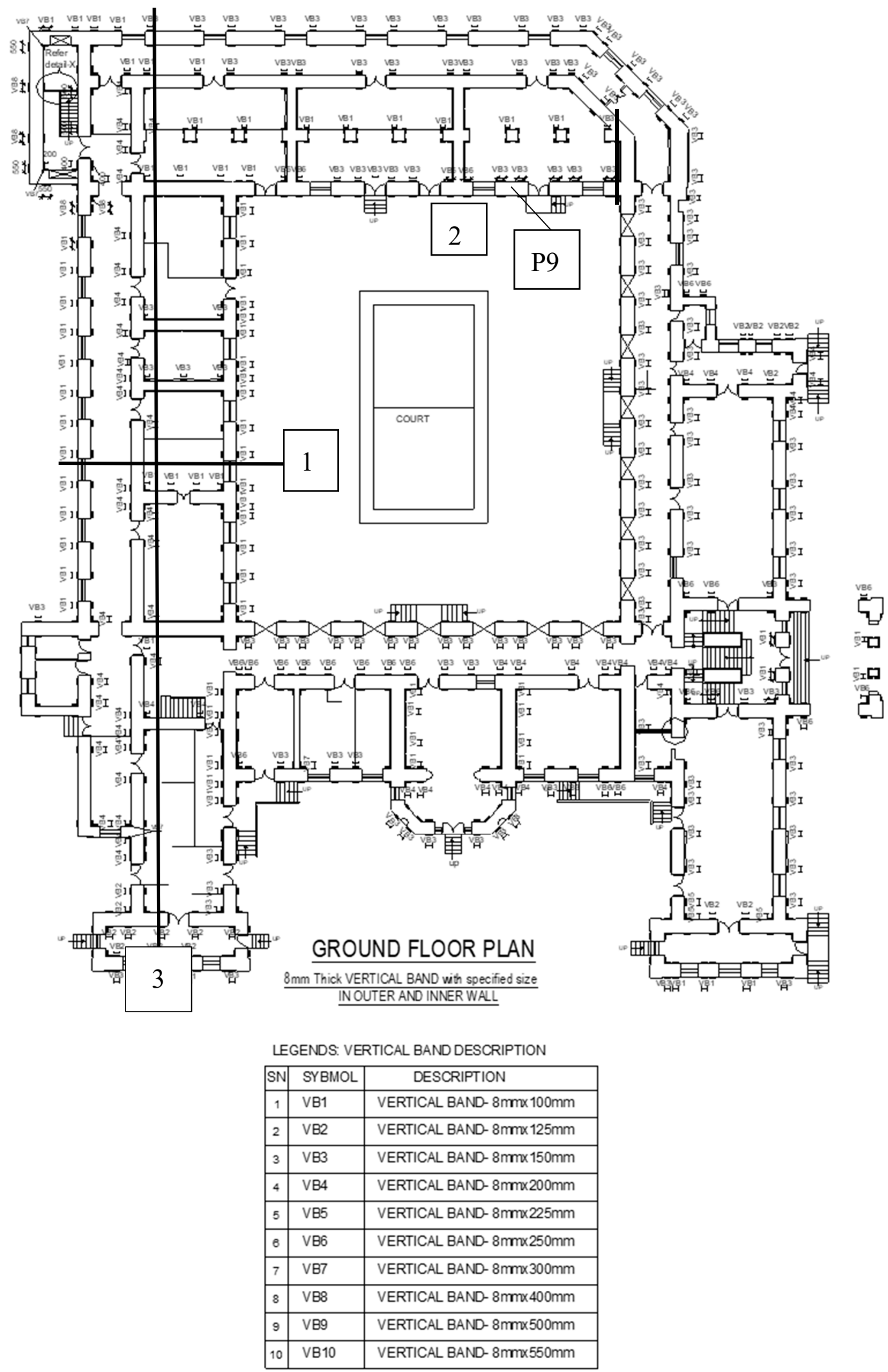

Figure 10. Retrofitting measures adopted for the monument (line and text in box indicates section-cut number and pier number). 
In flat roofs, coats of water proofing materials are required to prevent seepage. The timber in existing staircases was deteriorated. Hence, all staircases needed to be replaced by new, but similar, ones. The staircase projecting in the north-west corner was found to be especially vulnerable from analysis. The staircase of the exterior walls needed to be stiffened and anchored by the addition of ISMC-250 sections underneath the landing. Secure connections and ductility of the exterior architectural columns and porch were necessary for life safety. Decorative masonry columns were confined with vertical steel bars embedded around the columns by cutting the groves, and the entrance porch was tied with the main structure using horizontal bands at two levels. Provision of vertical bands around all openings and wide horizontal bands above openings help to redistribute the stress concentrated around openings. Arches were observed to be especially vulnerable in lateral shaking during past earthquakes, hence steel strips were used around arches to hold them to the nearby vertical band and horizontal lintel band.

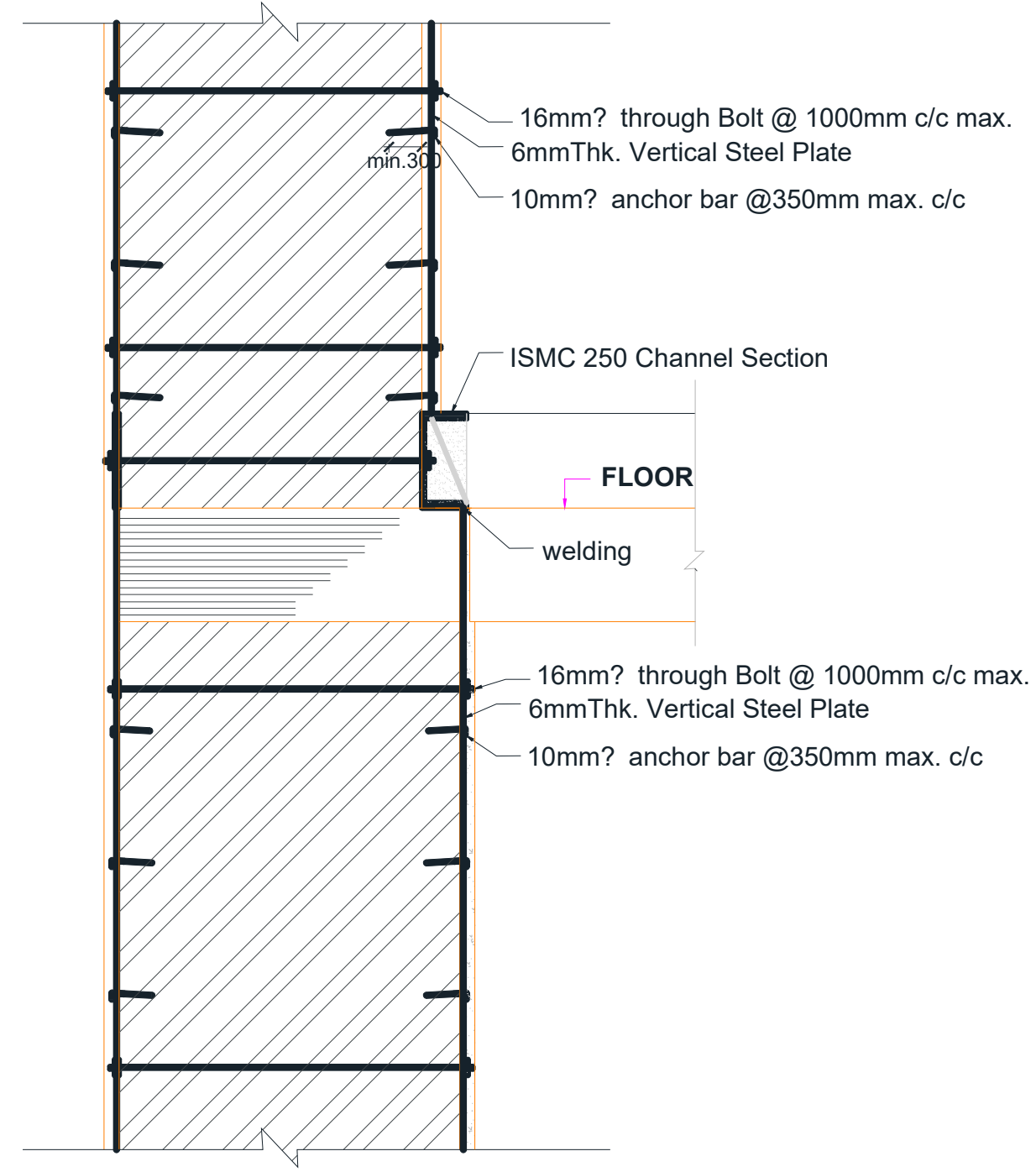

Figure 11. Details of band per floor.

The primary intervention system is composed of vertical and horizontal steel members which integrates and confines the masonry system; all such interventions would be hidden under the plaster to preserve the morphology of the monument. Strengthening of floors is done by providing floor braces and continuous beams at the floor levels. The shear strength of walls is enhanced by providing vertical steel members at the ends with horizontal bands and diagonal braces on walls at the selected 
locations. The sizing, position, and their connections are based on the analysis results. These elements are designed to resist the stress beyond the capacity of the existing wall. The stresses in the wall were computed as the ratio of internal forces per meter to the thickness of the corresponding wall as shown in Figures 14-16. Although examples are shown for different load combinations, the most critical cases were considered to perform necessary analysis and retrofit design.

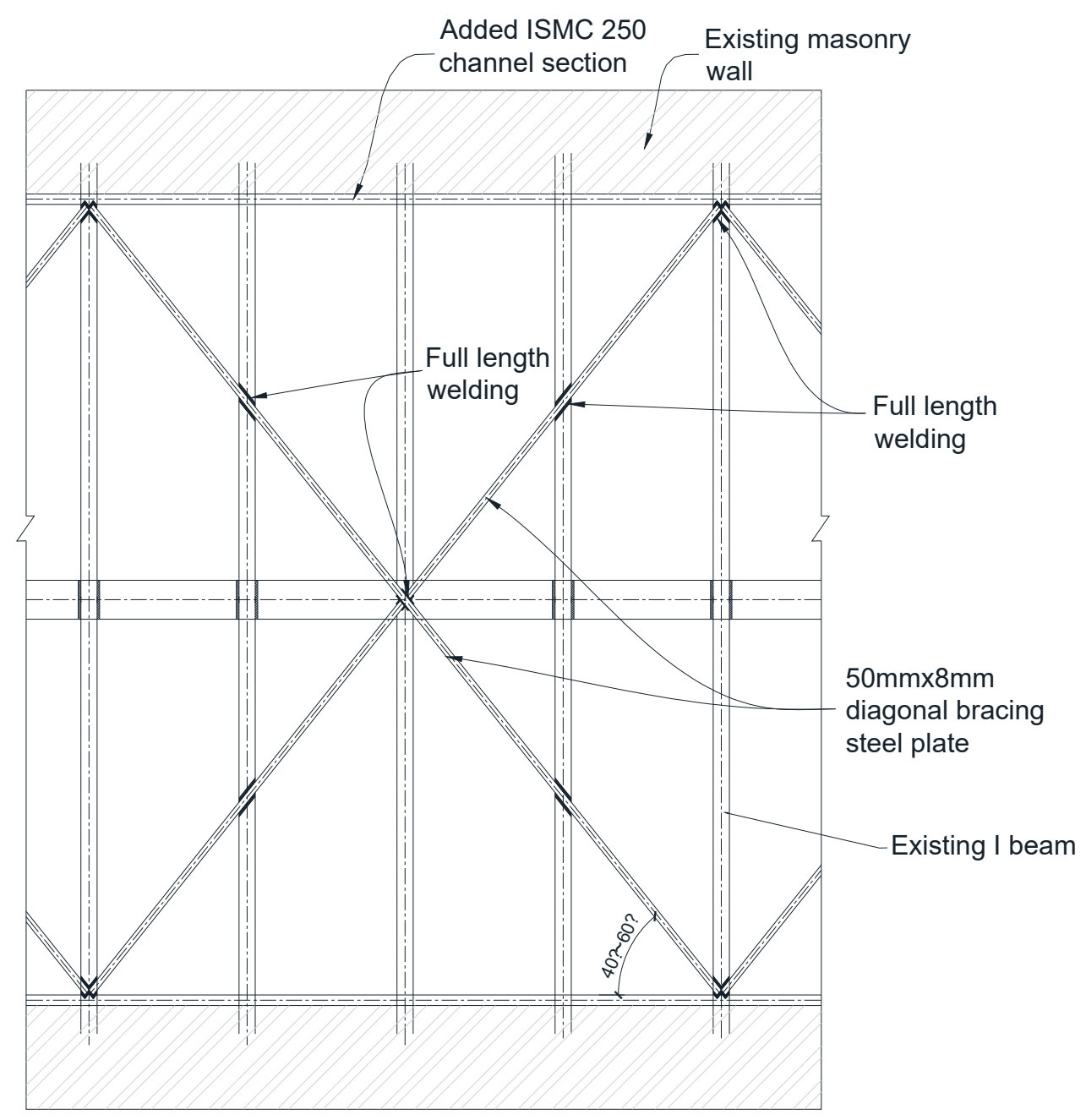

Figure 12. Details of bracing. 


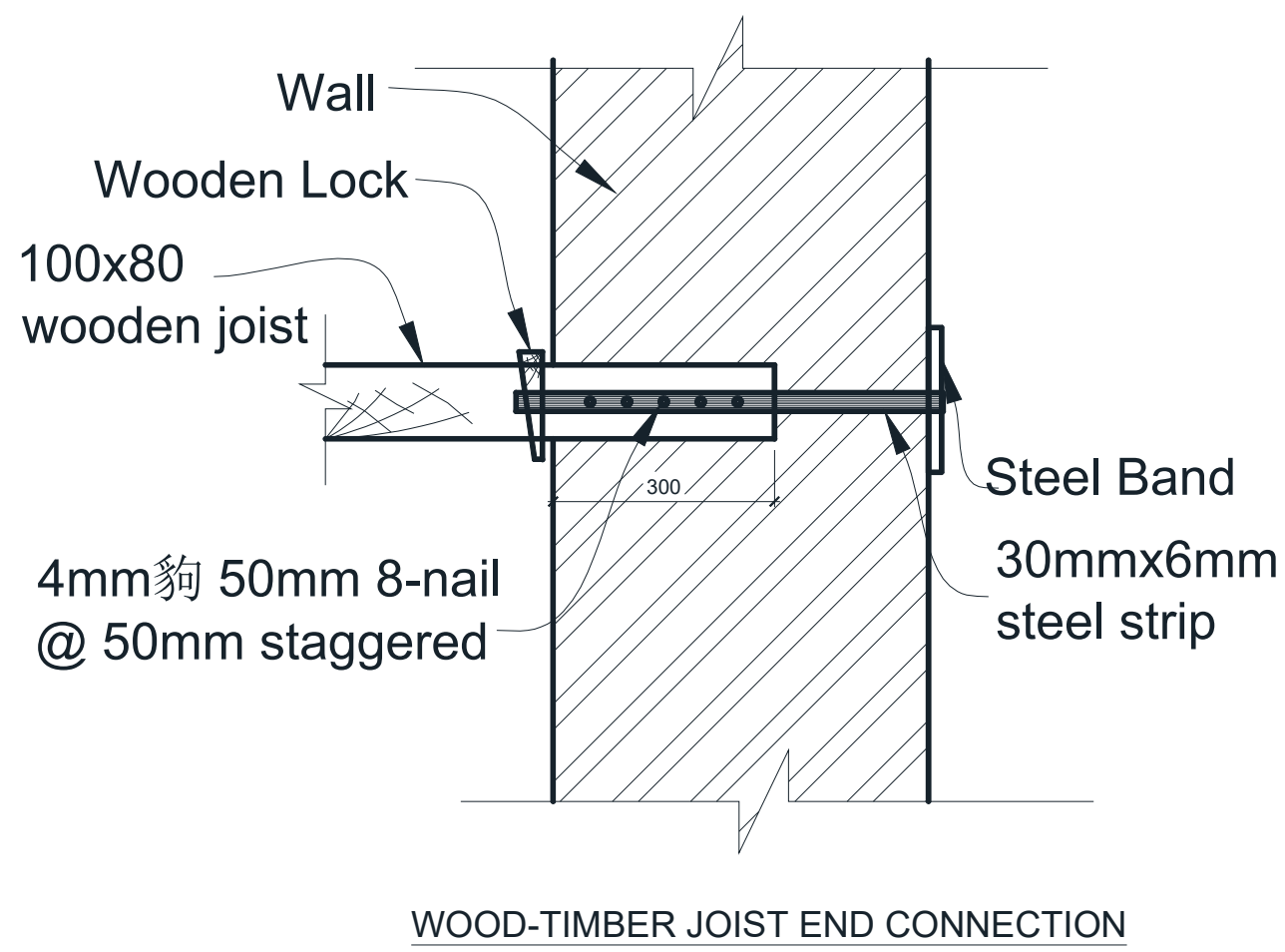

Figure 13. Details of timber joist end connection.

Tensile stresses were concentrated around opening and pier edges only due to the in-plane action of the earthquake load as indicated by Figure 14. There was an uplift in some portion of the piers, but due to development of tensile cracks, stresses were redistributed. Vertical steel plates are provided along the edges of each pier to take these stresses. Hence, tensile cracks are not allowed to propagate and subsequently prevent the masonry degradation in the cyclic load. Compressive stresses were also concentrated around opening, corners, and pier edges (see Figures 14-16). Although average compressive stress was obtained to be less than the average compressive strength of the walls; it was still higher than the permissible design stress. The provided steel plates that are stiffly anchored to walls take part in the compression of the wall to keep the stress within safe limits. Further, the confinement with vertical and horizontal steel bands increases the ductility and compressive strength of the wall, which is not considered in the calculation, and regarded as an additional factor of safety. Most masonry piers experienced higher shear stress than their design capacity. However, the design capacity of the wall was identified as $\sim 0.1 \mathrm{MPa}$, but because of high damping in mud-mortar structures, the actual damages would be generally lesser.

Improving the structure with ductile bands assure advantages in two ways. Firstly, it improves the ductility of the overall structure, requiring lesser design force, and secondly, these bands also increase the capacity of the structure. The sizing of these members is done based on the demand observed from response spectrum analysis in the FEM model. Engineering judgments were used in predicting the actual non-linear behavior of the structure and providing suitable adjustments in the required interventions. Figure 17a,b show the displacements in the $\mathrm{x}$ - and $\mathrm{y}$-directions, respectively, before retrofitting. The maximum displacements in the $\mathrm{x}$ - and $\mathrm{y}$-directions were noted as $40.65 \mathrm{~mm}$ and $33.54 \mathrm{~mm}$, respectively. The maximum displacement along the $\mathrm{x}$-axis was obtained in the east wall which was the most damaged wall. Similarly, the maximum displacement along the y-axis was obtained in the southern part of the monument where damage was also significant. Figure $17 \mathrm{c}, \mathrm{d}$ reflect the displacements along the $x$ - and $y$-axis after retrofitting. The inter-story drift was limited to $0.26 \%$ which indicates satisfactory performance level (immediate occupancy level) during the earthquake, provided the integrity of all the components is maintained. The maximum deformations along the 
$\mathrm{x}$-axis were $22.6 \mathrm{~mm}$ on the west wall, whereas, the same for the $\mathrm{y}$-axis was $16.9 \mathrm{~mm}$ on the south wall of the monument.

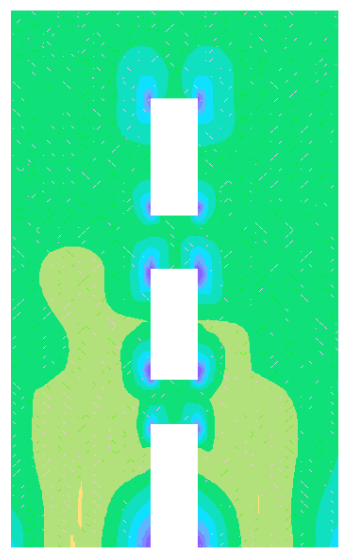

(a)

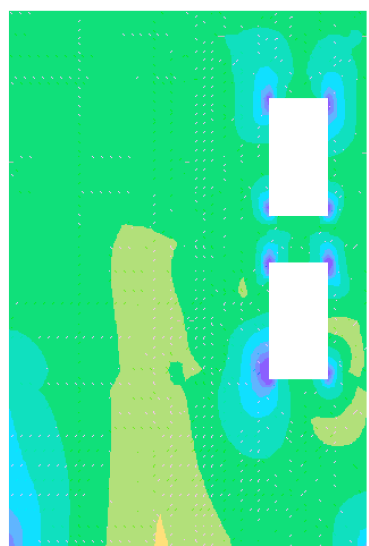

(b)

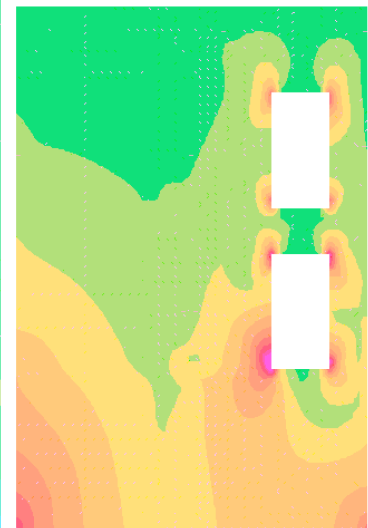

(c)

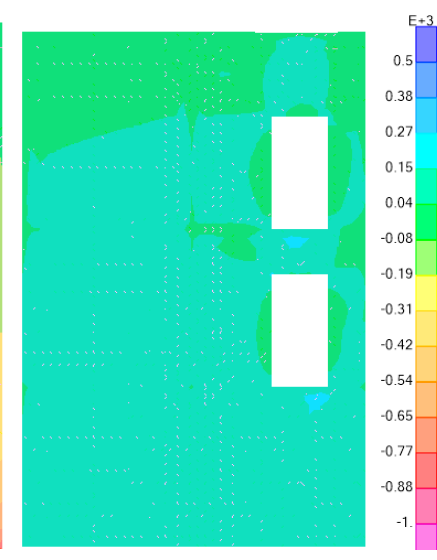

(d)

Figure 14. Force per meter under load combination dead + live + response spectrum-x (a) tensile force at section cut-1, (b) tensile force at section cut-2, (c) compressive force at section cut-2, and (d) shearing force at section cut-2. (See Figure 10 for section cuts).

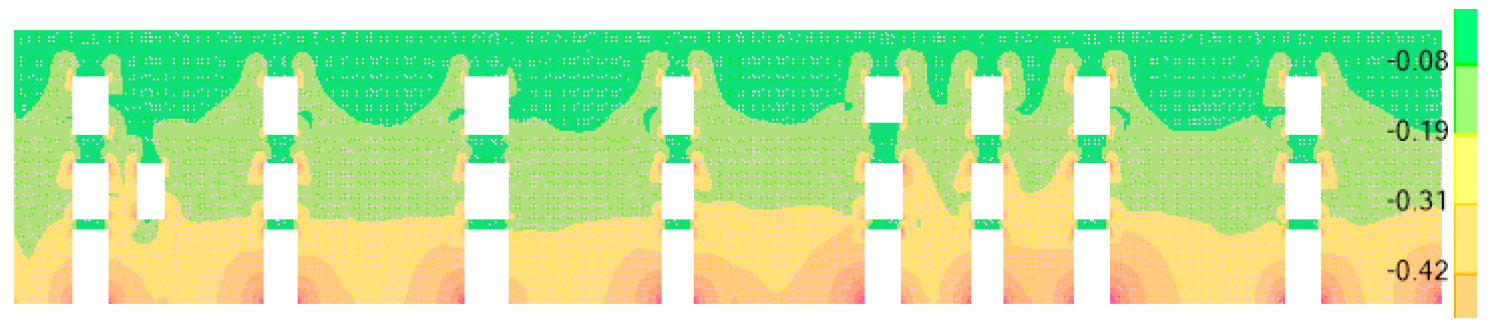

Figure 15. Compressive force per meter at section cut-3 (Figure 10) under load combination dead + live + response spectrum-x.

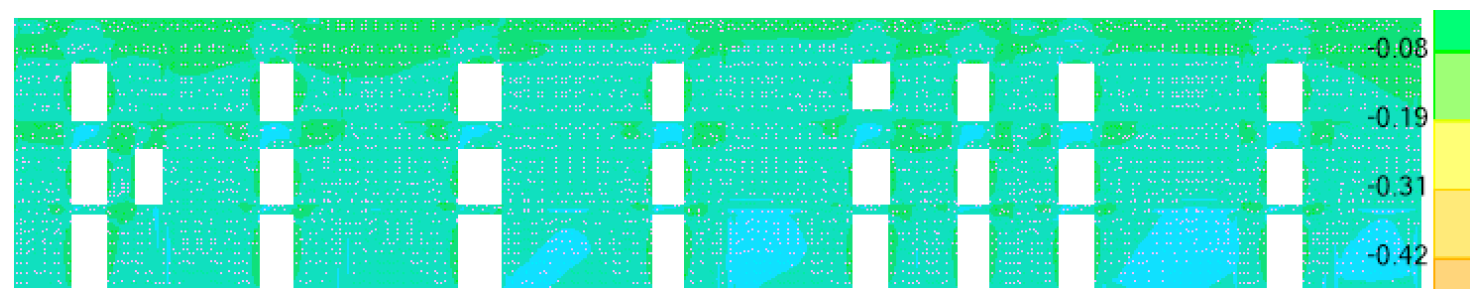

Figure 16. Shearing force per meter at section cut-3 (Figure 10) under load combination dead + live + response spectrum-x. 


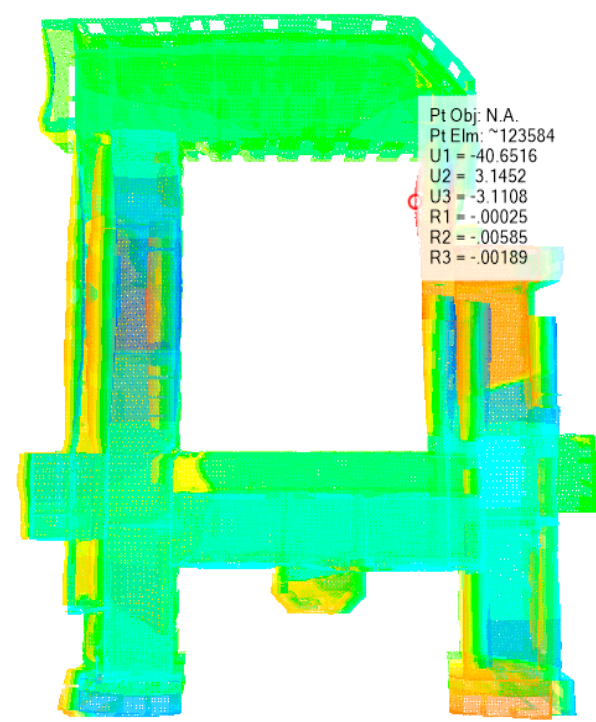

(a)

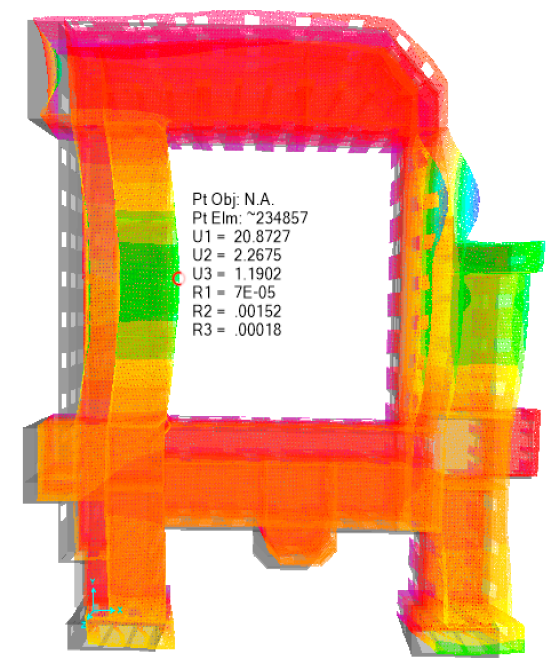

(c)

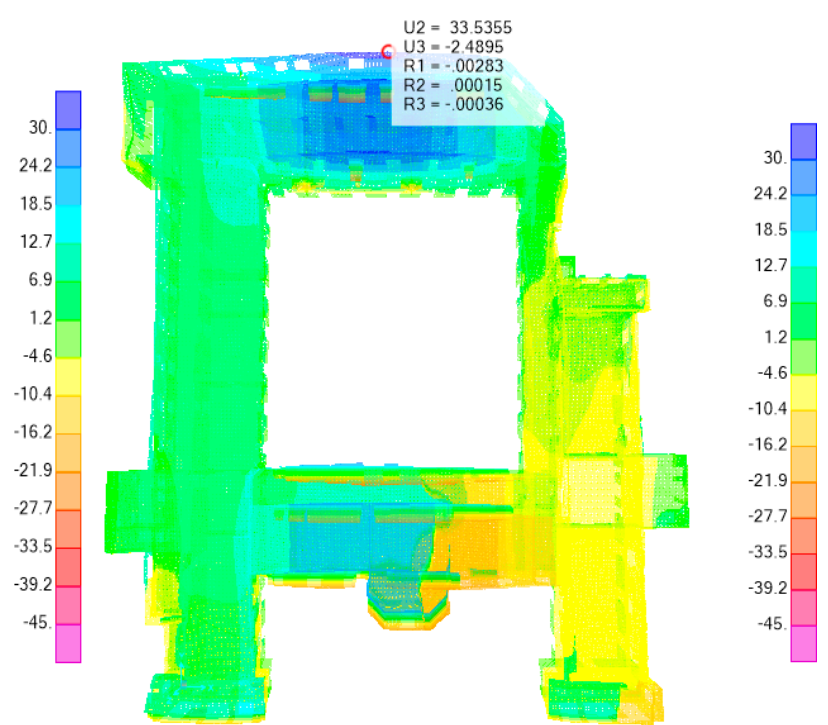

(b)

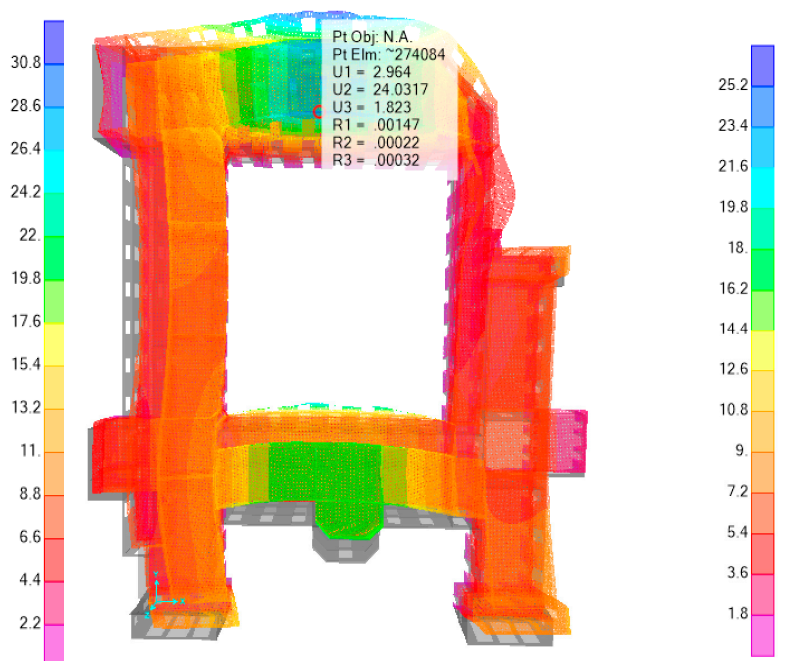

(d)

Figure 17. Deformation of the monument (a) before retrofitting along the x-direction, (b) before retrofitting along the $y$-direction, (c) after retrofitting along the $\mathrm{x}$-direction, and (d) after retrofitting in the y-direction.

Figure 18 shows the three-dimensional view of the pier P9 indicated in Figure 10. The section cut force from the analysis for P9 shows an axial, shear, and moment demand of $743 \mathrm{KN}, 181 \mathrm{KN}, 332 \mathrm{KN}-\mathrm{m}$ respectively. Meanwhile, there was no direct tension on the pier. The analysis further showed that the pier was deficient in compression capacity and rocking shear capacity. To this end, $100 \times 8 \mathrm{~mm}$ vertical steel plates were provided at pier ends on both faces in addition to the horizontal plates at lintel and sill levels. Analysis including the strength of steel plates showed that the aggregate capacity exceeds the demand forces. The same approach was used for all piers and safety checks were performed. 


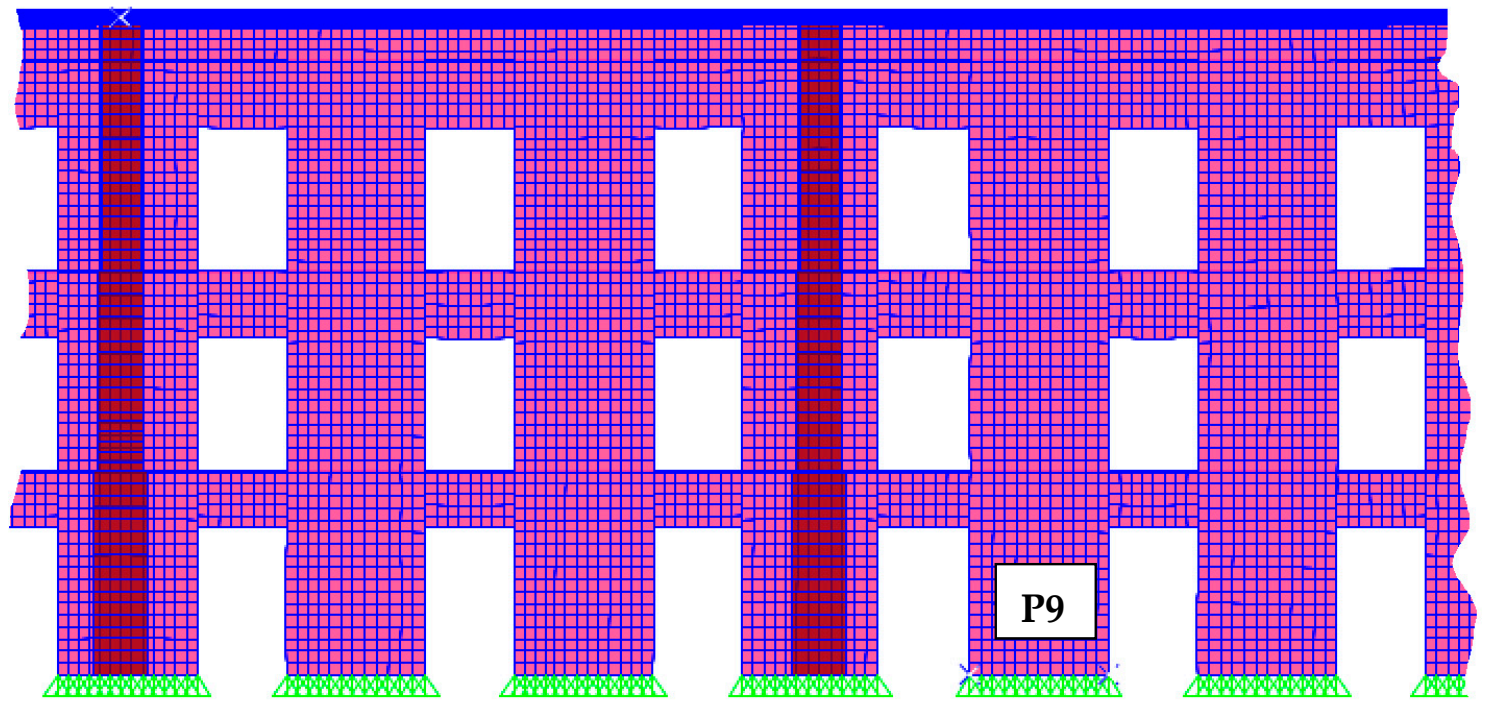

Figure 18. Elevation of wall showing the considered pier P9 (see Figure 10).

\section{Conclusions}

Restoration of Nepalese heritage buildings is a relevant topic in relation to their monumental and functional values. In the present paper, Bagh Durbar monumental building, a 19th-century landmark construction, was taken as a case study. As Greco-Roman constructions are still in considerable number and have monumental value, assessment and strengthening is a pertinent topic in Nepal. To achieve this objective, structural analyses and design of strengthening solutions were performed in this study. Cultural preservation and seismic safety were considered vis-a-vis and strengthening solutions were proposed in such a way that no morphological discrepancies would take place. Observation of the building conditions after the Gorkha earthquake and the characterization of the damage state confirmed a number of vulnerable features of the structural system. In compliance with national and international standards on existing structures, a two-phase process was adopted in this study. The first phase was associated with the comprehensive knowledge of the structure, including material properties and structural detailing. The second one consisted of the definition of a structural model to be loaded by means of conventional actions: the performance level in the current state and the performance level after implementation of specific interventions aimed at removing critical issues and increasing the strength and ductility of different components. It is shown that the localized non-compliances which occurred in the as-built model are significantly improved by the proposed interventions. This is one of the main outcomes of the paper, in the sense that a rational and virtuous process can preserve Greco-Roman monuments that are still widely used for administrative purposes, especially in the Kathmandu valley, by increasing at the same time their seismic safety. Apart from their administrative value, they have monumental values too; thus, field investigation, numerical analysis, and subsequent retrofit designs would be important to preserve them. The same retrofit option may be applicable to other monuments in the Kathmandu valley as the construction system and age of almost all Greco-Roman buildings matches.

In conclusion, it is worth noting that the level of the structural analysis discussed in this paper represents a point of balance between the ease-of-use of the representation of the seismic action (response spectrum), and the complexity of the two-dimensional representation of the walls and spandrels in the masonry building. Nevertheless, this is not necessarily a limitation of the approach that can be improved by including additional levels of analysis. In such a case, it is also clear that the detail of the structural and material knowledge needs to be increased to cover the requirements of refined and detailed constitutive laws of the materials and of the main structural components. Furthermore, one of the limitations of this work is that strengthening solutions are explored based on basic engineering principles to assure compliance with the existing guidelines that are practiced in Nepal (i.e., Nepali 
and Indian building codes only). So future studies may incorporate other international standards and practices to improve the outcomes.

Author Contributions: Conceptualization, R.A. and P.J.; methodology, G.F.; software, R.A., P.J., and D.G.; validation, G.F. formal analysis, R.A., and D.G.; investigation, P.J.; resources, P.J.; writing-original draft preparation, D.G. and R.A.; writing—review and editing, G.F., D.G. and R.A.; supervision, G.F.

Funding: This research received no external funding.

Acknowledgments: The authors are grateful to Digicon Engineering Consult, Kupandole for the arrangements. For the laboratory tests, Multi Lab and NS Engineering and Geotechnical Services Pvt. Ltd. are acknowledged. The support from various people at Kathmandu Metropolitan City Office is also greatly acknowledged. Suggestions from Professor Filippo Santucci de Magistris are also warmly acknowledged.

Conflicts of Interest: The authors declare no conflicts of interest.

\section{References}

1. National Planning Commission. Post-Earthquake Damage Assessment; Government of Nepal, National Planning Commission: Kathmandu, Nepal, 2015; Volume A and B.

2. Gautam, D.; Fabbrocino, G.; Santucci de Magistris, F. Derive empirical fragility functions for Nepali residential buildings. Eng. Struct. 2018, 171, 617-628. [CrossRef]

3. Pandit, A.K.; Yadav, R.; Jha, S.K.; Adhikari, R. Seismic vulnerability assessment of masonry buildings in Kathmandu Valley after Gorkha Earthquake 2015: A case study of Administrative Staff College building. In Proceedings of the International Conference on Earthquake Engineering and Post Disaster Reconstruction Planning, Bhaktapur, Nepal, 24-26 April 2016; pp. 244-251.

4. Langenbach, R. Performance of the earthen Arg-e-Bam (Bam Citadel) during the $2003 \mathrm{Bam}$, Iran, earthquake. Earthq. Spectra 2005, 21, S345-S374. [CrossRef]

5. D'Ayala, D.; Benzoni, G. Historic and traditional structures during the 2010 Chile earthquake: Observations, codes, and conservation strategies. Earthq. Spectra 2012, 28, S425-S451. [CrossRef]

6. Lucibello, G.; Brandonisio, G.; Mele, E.; De Luca, A. Seismic damage and performance of Palazzo Centi after L'Aquila earthquake: A paradigmatic case study of effectiveness of mechanical steel ties. Eng. Fail. Anal. 2013, 34, 407-430. [CrossRef]

7. Mazzoni, S.; Castori, G.; Galasso, C.; Calvi, P.; Dreyer, R.; Fischer, E.; Fulco, A.; Sorrentino, L.; Wilson, J.; Penna, A.; et al. 2016-17 Central Italy Earthquake Sequence: Seismic retrofit policy and effectiveness. Earthq. Spectra 2018. [CrossRef]

8. Ferreira, T.M.; Vicente, R.; Mendes da Silva, J.A.R.; Varum, H.; Costa, A. Seismic vulnerability assessment of historical urban center in Seixal, Portugal. Bull. Earthq. Eng. 2013, 11, 1753-1773. [CrossRef]

9. Vicente, R.; Rodrigues, H.; Varum, H.; Mendes Da Silva, J.A.R. Evaluation of strengthening techniques of traditional masonry buildings: Case study of four-building aggregate. J. Perform. Constr. Facil. 2011, 25, 202-216. [CrossRef]

10. Lamego, P.; Lourenco, P.B.; Sousa, M.L.; Marques, R. Seismic vulnerability and risk analysis of the old building stock at urban scale: Application to a neighborhood in Lisbon. Bull. Earthq. Eng. 2017, 15, 2901-2937. [CrossRef]

11. Asteris, P.G.; Chronopoulos, M.P.; Chrysostomou, C.Z.; Varum, H.; Plevris, V.; Kyriakides, N.; Silva, V. Seismic vulnerability assessment of historical masonry structural systems. Eng. Struct. 2014, 62-63, 118-134. [CrossRef]

12. de Felice, G.; De Santis, S.; Lourenco, P.B.; Mendes, N. Methods and challenges for the seismic assessment of historic masonry structures. Int. J. Archit. Herit. 2017, 11, 143-160. [CrossRef]

13. Casapulla, C.; Maione, A.; Argiento, L.C. Seismic analysis of an existing masonry building according to the multi-level approach of the Italian guidelines on cultural heritage. Ingegneria Sismica 2017, 34, 40-59.

14. Clementi, F.; Gazzani, V.; Poiani, M.; Mezzapelle, P.A.; Lenci, S. Seismic assessment of a monumental building through nonlinear analyses of a 3D solid model. J. Earthq. Eng. 2018, 22, 35-61. [CrossRef]

15. Lagomarsino, S.; Cattari, S. PERPETUATE guidelines for seismic performance-based assessment of cultural heritage masonry structures. Bull. Earthq. Eng. 2015, 13, 13-47. [CrossRef]

16. Milani, G.; Venturini, G. Safety assessment of four masonry churches by a plate and shell FE nonlinear approach. J. Perform. Constr. Facil. 2013, 27, 27-42. [CrossRef] 
17. Rossi, M.; Cattari, S.; Lagomarsino, S. Performance-based assessment of the great mosque of Algiers. Bull. Earthq. Eng. 2015, 13, 369-388. [CrossRef]

18. Marra, A.; Brigante, D.; Rainieri, C.; Fabbrocino, G. Structural characterization and performance assessment of the Villa d'Este Palace in Tivoli. In Proceedings of the 16th International Brick and Block Masonry Conference "Masonry in a world of challenges", Padua, Italy, 26-30 June 2016.

19. Fabbrocino, G.; Marra, A.; Savorra, M.; Fabbrocino, S.; Santucci de Magistris, F.; Rainieri, C.; Brigante, D.; Celiento, A. Increasing the resilience of cultural heritage to earthquakes by knowledge enhancement: The lesson of the Carthusian Monastery in Trisulti. In Resilienza Delle città D'arte ai Terremoti; Atti Dei Convegni Lincei; Accademia Nazionale dei Lincei: Roma, Italy, 2016; Volume 306, pp. 553-566.

20. Sonda, D.; Miyamoto, K.; Kast, S.; Khanal, A. The restoration and seismic strengthening of the earthquake-damaged UNESCO heritage palace in Kathmandu. Int. J. Archit. Herit. 2018. [CrossRef]

21. Gautam, D. Seismic performance of world heritage sites in Kathmandu valley during Gorkha seismic sequence of April-May 2015. J. Perform. Constr. Facil. 2017. [CrossRef]

22. DUDBC (Department of Urban Development and Building Construction). Seismic Vulnerability Evaluation of Guideline for Private and Public Buildings; Government of Nepal, Department of Urban Development and Building Construction: Kathmandu, Nepal, 2011.

23. Grunthal, G. European Macroseismic Scale 1988 (EMS-1988); Centre Européen de Géodynamique et de Séismologie: Luxemburg, 1998.

24. NBC (Nepal Building Code). Seismic Design of Buildings in Nepal (NBC-105); Government of Nepal, Department of Urban Development and Building Construction: Kathmandu, NBC, Nepal, 1994.

25. Recommendations PCM. Guidelines for the Assessment and the Mitigation of Seismic Risk of Cultural Heritage with Reference to Italian NTC2008; Directive of the Prime Minister: Rome, Italy, 2011. (In Italian)

26. FEMA (Federal Emergency Management Agency). NEHRP Guidelines for Seismic Rehabilitation of Buildings; Federal Emergency Management Agency Report (FEMA-273); FEMA: Washington, DC, USA, 1997.

27. Rainieri, C.; Fabbrocino, G.; Verderame, G.M. Non-destructive characterization and dynamic identification of a modern heritage building for serviceability seismic analyses. NDT E Int. 2013, 60, 17-31. [CrossRef]

28. Rainieri, C.; Fabbrocino, G. Development and validation of an automated operational modal analysis algorithm for vibration-based monitoring and tensile load estimation. Mech. Syst. Signal Process. 2015, 60-61, 512-534. [CrossRef]

29. Rainieri, C.; Marra, A.; Rainieri, G.M.; Gargaro, D.; Pepe, M.; Fabbrocino, G. Integrated non-destructive assessment of relevant structural elements of an Italian heritage site: The Carthusian monastery of Trisulti. J. Phys. Conf. Ser. 2015, 628, 012018. [CrossRef]

30. CSI (Computer and Structure Inc). SAP: Integrated Software for Structural Analysis and Design; v. 20; CSI: Walnut Creek, CA, USA, 2000.

31. Bureau of Indian Standards (BIS). Indian Standard Criteria for Earthquake Resistant Design of Structures: Part 1 General Provisions and Buildings (Fifth Revision); IS 456 (Part 1); BIS: New Delhi, India, 2016.

32. Bureau of Indian Standards (BIS). Indian Standard Code of Practice for Structural Use of Unreinforced Masonry; Bureau of Indian Standard: New Delhi, India, 1987.

(C) 2019 by the authors. Licensee MDPI, Basel, Switzerland. This article is an open access article distributed under the terms and conditions of the Creative Commons Attribution (CC BY) license (http://creativecommons.org/licenses/by/4.0/). 